\title{
Revision and redescription of the species previously included in the genus Amphilaphis Studer and Wright in Studer, 1887 (Octocorallia: Primnoidae)
}

\author{
REBECA ZAPATA-GUARDIOLA and PABLO J. LÓPEZ-GONZÁLEZ \\ Departamento de Fisiología y Zoología, Facultad de Biología, Universidad de Sevilla, Reina Mercedes 6, 41012-Sevilla, \\ Spain.E-mail: rzapata@us.es pjlopez@us.es
}

\begin{abstract}
SUMMARY: The taxonomy of the primnoid genus Amphilaphis Studer and Wright in Studer, 1887 has been in a confused state for a long time and a revision of the species included in that genus has become a necessity. We have revised and redescribed the species previously included in the genus using up-to-date technology, such as polyp and sclerite images obtained with scanning electron microscopy (SEM). As a result of this study, because the type species of Amphilaphis is actually a Thouarella species, we consider the genus Amphilaphis to be no longer valid. One of the species previously considered in Amphilaphis has a set of morphological characters that are not recognizable in any of the current primnoid genera. Primnocapsa n. gen. has a dichotomous branching pattern, polyps placed singly, in spirals around the branchlets, 8 opercular scales with the inner surface keeled and with 2 mounds basally and 8 marginal scales offset from the operculars. The new genus is described and illustrated. Moreover, one of the re-examined species has been included in a new subgenus, Faxiella n. subgen. of Plumarella Gray, 1870 because it has polyps placed in pairs. Finally, the remaining re-examined species have been included in the genus Thouarella Gray, 1870, one of the most specious primnoid genera.
\end{abstract}

Keywords: Cnidaria, new genus, new subgenus, Faxiella, Primnocapsa, Thouarella.

RESUMEN: REVISIÓN Y REDESCRIPCIÓN DE LAS ESPECIES INCLUIDAS PREVIAMENTE EN EL GÉNERO AMPHILAPHIS STUDER Y Wright en Studer, 1887 (Octocorallia: Primnoidae). - Durante mucho tiempo, el género de primnoido Amphilaphis Studer y Wright en Studer, 1887, ha sido un cajón de sastre y la revisión de las especies incluidas en este género se ha convertido en algo indispensable. Mediante el uso de la tecnología más actual, como es la microscopía electrónica de barrido (SEM), para la obtención de imágenes de pólipos y escleritos, hemos revisado y redescrito todas las especies previamente incluidas en el género. Como resultado de este estudio, y dado que la especie tipo de Amphilaphis es de hecho una especie perteneciente al género Thouarella, concluimos que el género Amphilaphis no debería considerarse válido. Una de las especies previamente consideradas en este género presenta un conjunto de caracteres morfológicos no reconocibles en ningún género de primnoido. Primnocapsa n. gen. se caracteriza por tener un patrón de ramificación dicotómico, pólipos aislados dispuestos en espiral alrededor de las ramas, ocho escamas operculares con quilla y con dos protuberancias basales y ocho escamas marginales dispuestas de forma alterna con las operculares. El nuevo género es descrito e ilustrado. Además, una de las especies re-examinadas ha sido incluida en un nuevo subgénero, Faxiella n. subgen. de Plumarella Gray, 1870 por poseer pólipos dispuestos en pares. Por último, las restantes especies re-examinadas han sido incluidas en el género Thouarella Gray, 1870, uno de los géneros de primnoidos con más especies.

Palabras clave: Cnidaria, nuevo género, nuevo subgénero, Faxiella, Primnocapsa, Thouarella.

\section{INTRODUCTION}

Primnoidae is one of the richest gorgonian families in terms of the number of genera and species (Bayer 1980, 1981, 1988, 1998). This family is present in both polar waters, north and south, and in deep wa- ters at temperate latitudes (Bayer 1996), dominating, together with the Isididae family, the high latitudes of the Southern Hemisphere (Alderslade 1998, Bayer 1998, López-González and Gili 2002). According to Cairns and Bayer (2009), 36 genera with 233 species are currently recognized for Primnoidae, although new 


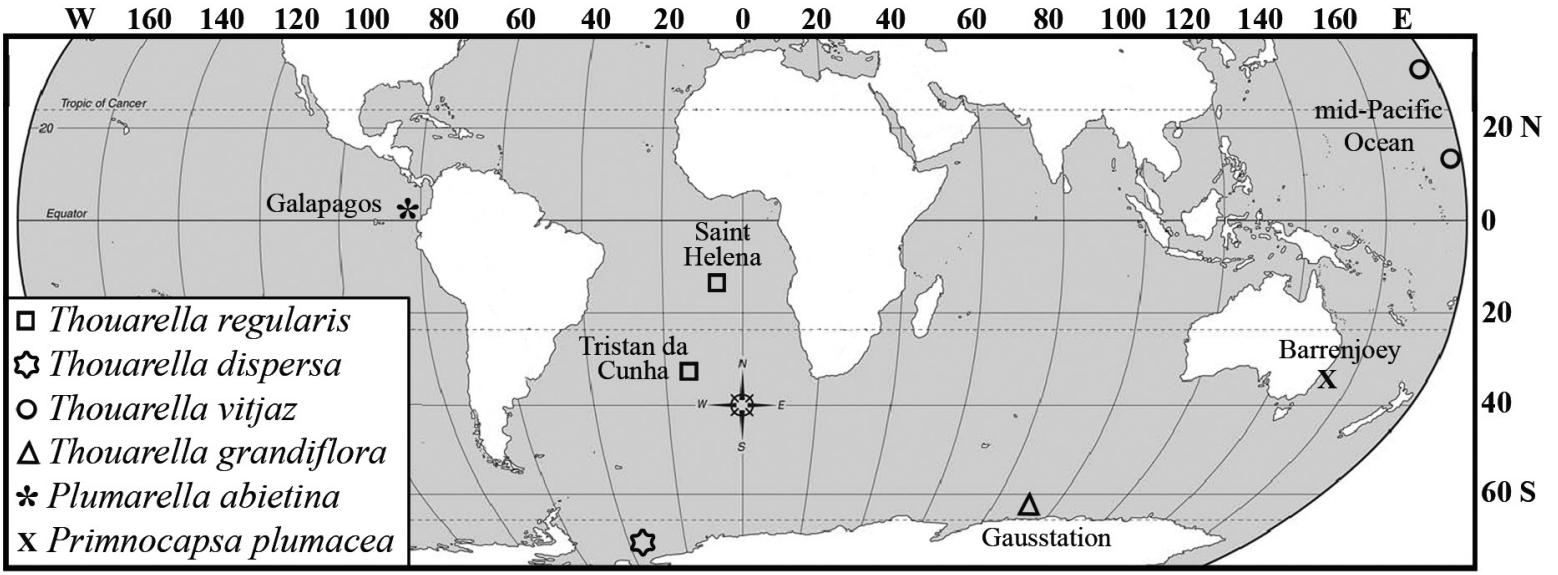

FIG. 1. - Known distribution of primnoid species studied in this paper: square, Thouarella regularis; star, T. dispersa, Antarctica, no specific location; circle, T. vitjaz n. sp.; triangle, T. grandiflora; asterisk, Plumarella (Faxiella) abietina; cross, Primnocapsa plumacea.

species and genera are constantly being proposed (see for example Zapata-Guardiola and López-González 2010a,b,c, and Cairns 2010).

The genus Amphilaphis Studer and Wright in Studer (1887) is one of the least cohesive primnoid genera. Since its original description it has been placed either inside or outside of the related genus Thouarella by different authors (Kükenthal 1912, 1915, Bayer 1981, Bayer and Stefani 1989). Furthermore, up to 8 species have been included in the genus by previous authors (Wright and Studer 1989, Nutting 1908, Thomson and Mackinnon 1911, Kükenthal 1915). In an initial attempt, Cairns and Bayer (2009) transferred 2 of them to the genus Thouarella, while the remaining species were tentatively maintained in Amphilaphis. Due to this ongoing uncertainty we considered it appropriate to revise the 6 species currently assigned to Amphilaphis.

An effort is made herein to redescribe the species assigned to Amphilaphis under the current descriptive formats, revising the true recognizable distribution and, when possible, establishing relationships with the closest congeners. The study of the type material of the 6 species currently included in Amphilaphis, one of which is the type species of the genus, has allowed us to propose a series of changes in the placement of this group of primnoids. These changes include the allocation of 4 of the species (one of them the type species) to the genus Thouarella (this act invalidates the genus Amphilaphis), the establishment of a new subgenus of Plumarella and a new primnoid genus to accommodate Amphilaphis abietina Studer, 1894 and Amphilaphis plumacea Thomson and Mackinnon, 1911, respectively.

\section{MATERIALS AND METHODS}

The material of the species here examined is deposited in different museums around the world: the Australian Museum (AM), Sydney; The Natural History Museum (NHMUK), London; the Museum für
Naturkunde (ZMB), Berlin; the Museum of Comparative Zoology (MCZ), Harvard University, Cambridge; the Museum of Natural History (MNHW), Wroclaw University, Poland; the National Museum of Natural History (NMNH), the Smithsonian Institution, Washington DC; the Zoological Museum of Amsterdam (ZMA), the Netherlands, and the P.P. Shirshov Institute of Oceanology, Russian Academy of Sciences (IORAS), Russia. All of these institutions kindly sent us part of their specimens for scanning electron microscopy (SEM) examination of polyp and sclerite morphology. Fragments of the colonies were prepared for study by SEM employing the usual methodology previously described by several authors (e.g. Bayer and Stefani 1989, Alderslade 1998), and permanent mounts were made for light microscopy observation. In order to better observe the arrangement of the scales on the polyps using light microscopy, their outlines were usually highlighted by applying methylene blue. The colony and sclerite terminology herein mainly follows Bayer et al. (1983) and Cairns and Bayer (2009). Sclerite measurements are presented as the height range $\mathrm{X}$ the width range. The distribution of the species here studied is shown in Figure 1.

\section{RESULTS}

\section{Family PrimnOIDAe Gray, 1858 Genus Thouarella Gray, 1870}

Diagnosis. Primnoidae commonly with a bottlebrush colony shape and simple or ramified branchlets, or fan-shaped. Polyps cylindrical to club-shaped with 8 rows of body scales that decrease near calyx base, angled upward or almost perpendicular to stem, straight or adaxially incurved, and arranged singly or in whorls. Opercular scales usually keeled, 8 in number, arranged in 2 alternate cycles. Marginal scales also 8 in number with a keel or multiple keels, alternating in 2 cycles, and folding over the operculars in an indented way. Adaxial body scales often reduced in size and number. 


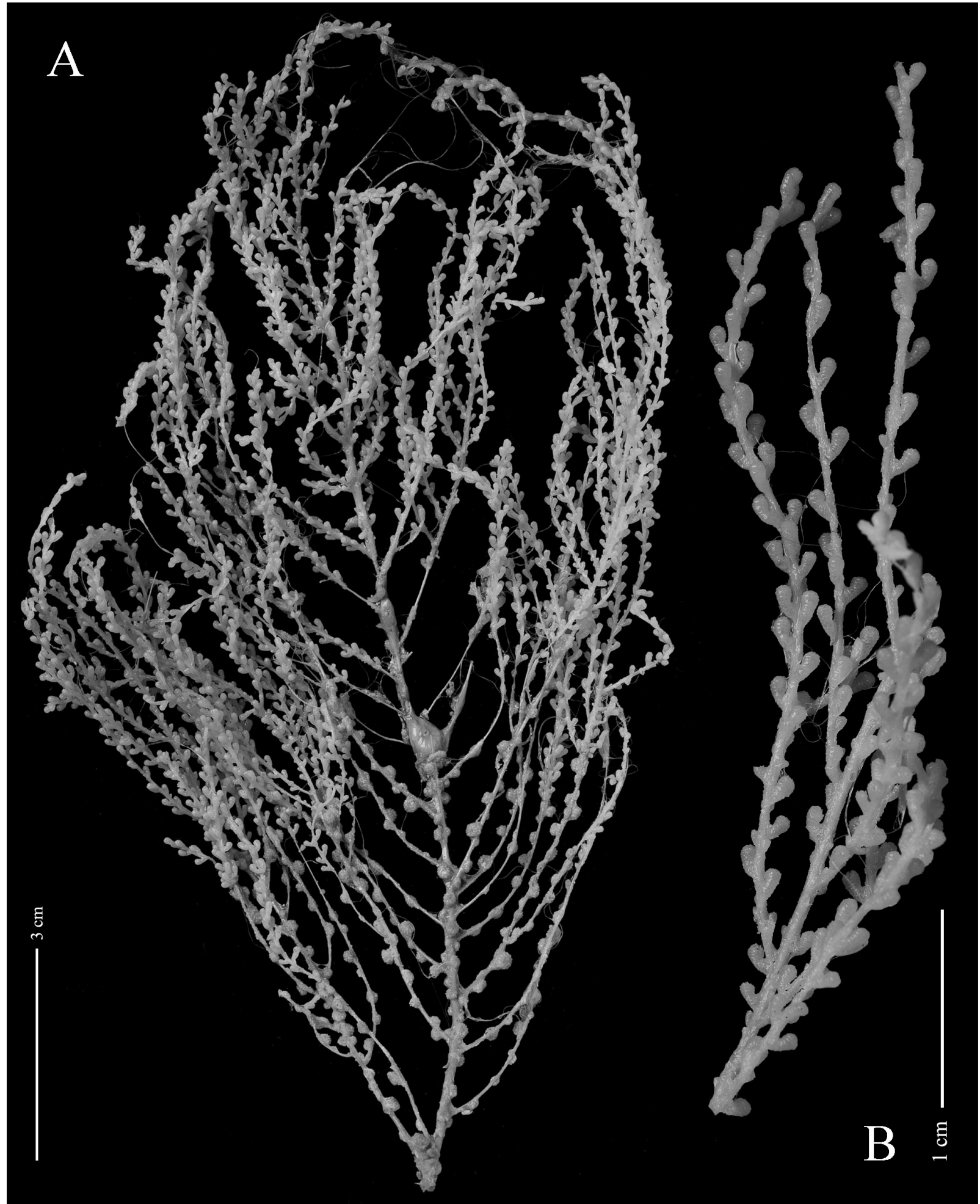

FIG. 2. - Thouarella regularis (Wright and Studer, 1889), lectotype (NHMUK 1889.5.27.60): A, whole colony; B, detail of branchlet.

Thouarella regularis (Wright and Studer, 1889)

$$
\text { (Figs. 2-6) }
$$

Amphilaphis regularis Wright and Studer 1889: 71-72; pl. 15, Figs. 1, 1a; pl. 21, fig. 7. Versluys 1906: 22. Thomson and Ritchie 1906: 854. Cairns and Bayer 2009: 28, 38; Fig. 10 j-q
Thouarella regularis, Kükenthal 1912: 307.

Thouarella (Amphilaphis) regularis, Kükenthal 1915: 149. Kükenthal 1919: 409-410. Kükenthal 1924: 289. Parrish and Baco 2007: 192.

not Thouarella regularis Kükenthal 1907: 206-207. [=Thouarella laxa Versluys, 1906]

not Amphilaphis regularis, Nutting 1908: 573-574. [=Plumarella circumoperculum Cairns, 2010] 

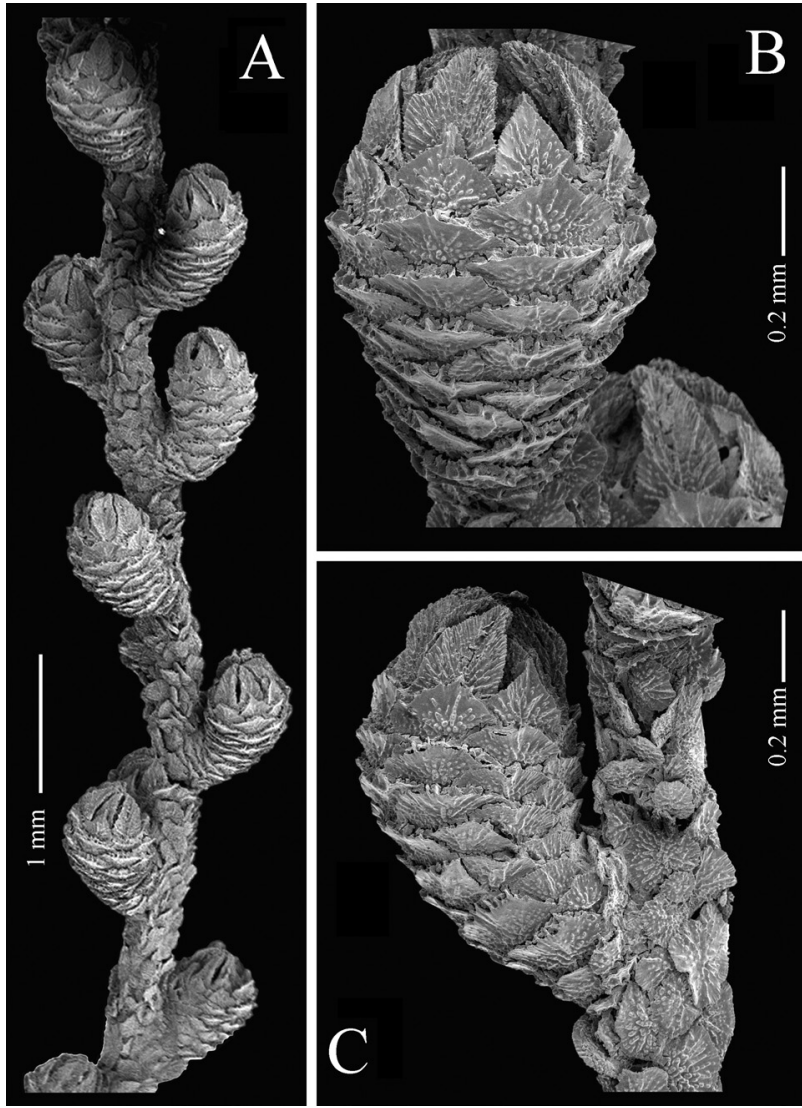

FIG. 3. - Thouarella regularis (Wright and Studer, 1889), lectotype (NHMUK 1889.5.27.60): A, detail of branchlet; B, polyp on abaxial view; C, polyp on lateral view.

Examined material. Lectotype (here designated): NHMUK 1889.5.27.60, on label: "Challenger Expedition, stn 135a, $37^{\circ} 16.83^{\prime} \mathrm{S}$ $12^{\circ} 45.25^{\prime} \mathrm{W}$, off Inaccessible Island, Tristan da Cunha, SubAntarctica, 137 m depth, 16 October 1873 ; stn $135 \mathrm{c}, 37^{\circ} 25.5^{\prime} \mathrm{S} 12^{\circ} 28.5^{\prime} \mathrm{W}$, off Nightingale Island, Tristan da Cunha, SubAntarctica, 183-274 $m$ depth, 17 October 1873". (According to the information on the label and that in the archives of the NHMUK, 2 close localities are indicated for the lectotype material here designated (stns. 135a and 135c) (Emma Sherlock, pers. comm.). Paralectotypes (here designated): NHMUK 1932.12.8.7, Challenger Expedition, stn 135, $37^{\circ} 1.83$ 'S $12^{\circ} 19.16^{\prime} \mathrm{W}$, off Tristan da Cunha, SubAntarctica, $658 \mathrm{~m}$ depth, 15 October 1873, one colony fragmented in several pieces; NHMUK 1889.7.5.11.15 and 1889.7.5.17, Challenger Expedition, stn $135 \mathrm{a}, 37^{\circ} 16.83^{\prime} \mathrm{S} 12^{\circ} 45.25^{\prime} \mathrm{W}$, off Inaccessible Island, Tristan da Cunha, SubAntarctica, $137 \mathrm{~m}$ depth, 16 October 1873, 5 colonies and more than 10 fragments; NHMUK 89.7.5.18 and 89.7.5.21, stn. $135 \mathrm{~b}, 37^{\circ} 22.5^{\prime} \mathrm{S} 12^{\circ} 33^{\prime} \mathrm{W}$, off Nightingale Island, Tristan da Cunha, SubAntarctica, $851 \mathrm{~m}$ depth, 17 October 1873, stn 135c, 37²5.5'S $12^{\circ} 28.5^{\prime} \mathrm{W}$, off Nightingale Island, Tristan da Cunha, SubAntarctica, $201 \mathrm{~m}$ depth, 17 October 1873 , stn $135 \mathrm{~d}, 37^{\circ} 25^{\prime} \mathrm{S} 12^{\circ} 30.5^{\prime} \mathrm{W}$, off Nightingale Island, Tristan da Cunha, SubAntarctica, 132 m depth, one colony each (according to the information on the label and that in the archives of the NHMUK, 3 close localities are indicated for both specimens). Additional material: ZMA COEL 04937, Scottish National Antarctic Expedition, Saint Helena, SubAntarctica, 1904.

Description of the lectotype. Colony fan-shaped, pinnately branched in one plane (Fig. 2A) $25 \mathrm{~cm}$ in high and $13 \mathrm{~cm}$ wide. Simple or pinnately ramified branchlets up to second order and inclined upward, terminal branchlets up to $9 \mathrm{~cm}$ long. Axis yellowish brown, holdfast present and attached to hard substrate
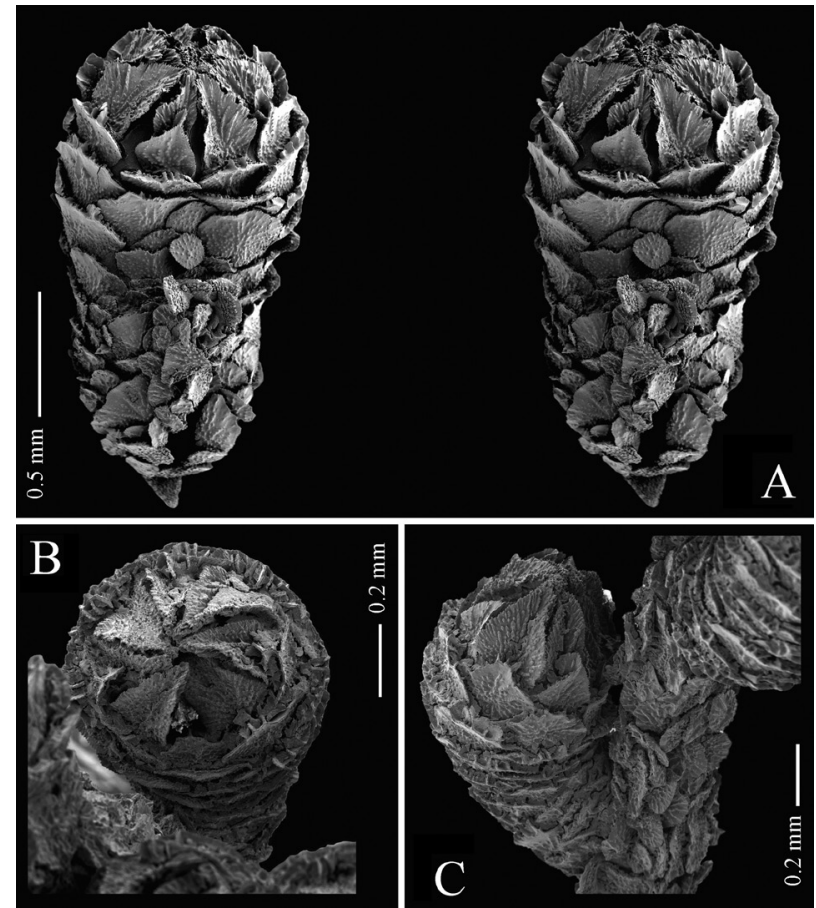

FIG. 4. - Thouarella regularis (Wright and Studer, 1889), lectotype (NHMUK 1889.5.27.60): A, polyp on adaxial view, stereo pair; B, polyp on oral view; C, polyp on latero-adaxial view.

(scleractinian coral), basal axis diameter of $4 \mathrm{~mm}$. Polyps (Fig. 2B, 3A) inclined upward to branchlets, singly placed, present on main stem, branches and branchlets, and arranged in spirals or biserially, 11-14 polyps per $\mathrm{cm}$. They are cylindrical to club-shaped (Fig. 3B, C), about $0.9-1.8 \mathrm{~mm}$ tall and $0.54-1.02 \mathrm{~mm}$ in greatest diameter, with body scales in 8 longitudinal rows. Each abaxial row has 7-9 scales (Fig. 3B) and there are 3-4 scales in each adaxial row that are slightly disorganized (Fig. 4A).

Eight opercular scales (Fig. 4B, 5A), 0.38$0.52 \times 0.19-0.3 \mathrm{~mm}$, pentagonal-shaped, slightly bilobed basally and with an acute apex. Proximal inner surface tuberculate covering up to half of the length. Prominent apical keel with multiple lateral ridges. Distal inner surface of scale with radial ridges. Outer surface radially granular from a basal nucleus. Basal margin with irregular processes, free margin finely serrated.

Eight marginal scales (Fig. 5B) $0.32-0.41 \times 0.27$ $0.34 \mathrm{~mm}$, pentagonal-shaped, with an acute apex. Inner surface tuberculate, covering at least the proximal half and up to about $80 \%$ of the length. Prominent apical keel with multiple lateral ridges, lateral inner distal surface almost smooth. Outer surface radially granular from a basal nucleus. Basal margin with irregular tuberculate processes, free margin finely serrated.

Body scales (Fig. 6A) 0.23-0.31×0.29-0.49 mm and fan-shaped. Inner surface almost completely tuberculate, short ridges in the middle of the distal margin decreasing in number and size from distal to basal scales; outer surface radially granular, basal margin 


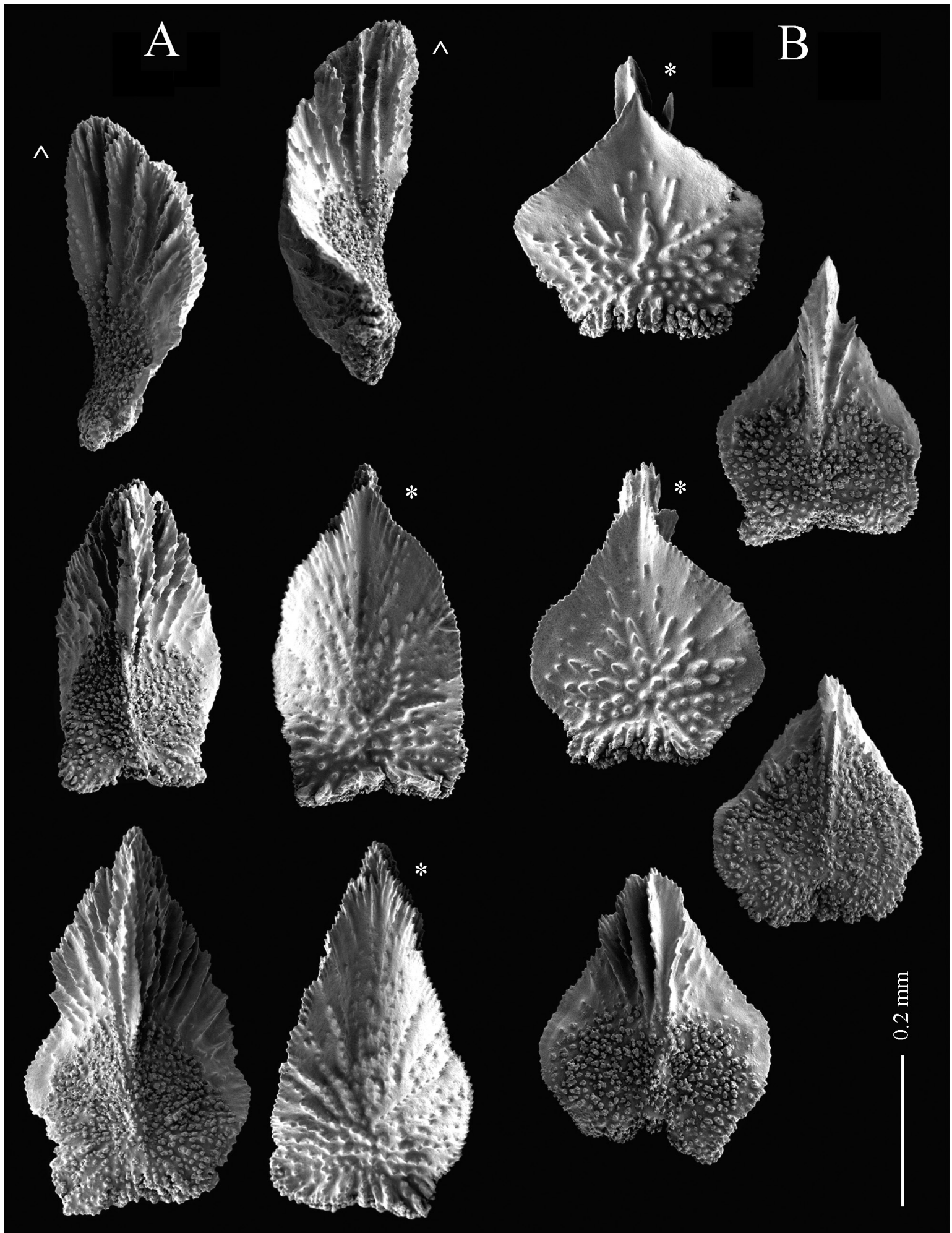

FIG. 5. - Thouarella regularis (Wright and Studer, 1889), lectotype (NHMUK 1889.5.27.60): A, opercular scales; B, marginal scales. [*outer surface view; ^ lateral view].

with irregular tuberculate processes, free margin finely serrated. Adaxials with tendency to be reduced in size.

Coenenchymal sclerites (Fig. 6B) in 2 layers: outer layer of round to oval-shaped, 0.07-0.3 mm maximum length. Inner surface completely tuberculate, outer surface with granules sometimes forming ridges. Margin similar to that of body scales. Inner layer consisting of tuberculate, irregular sclerites. 


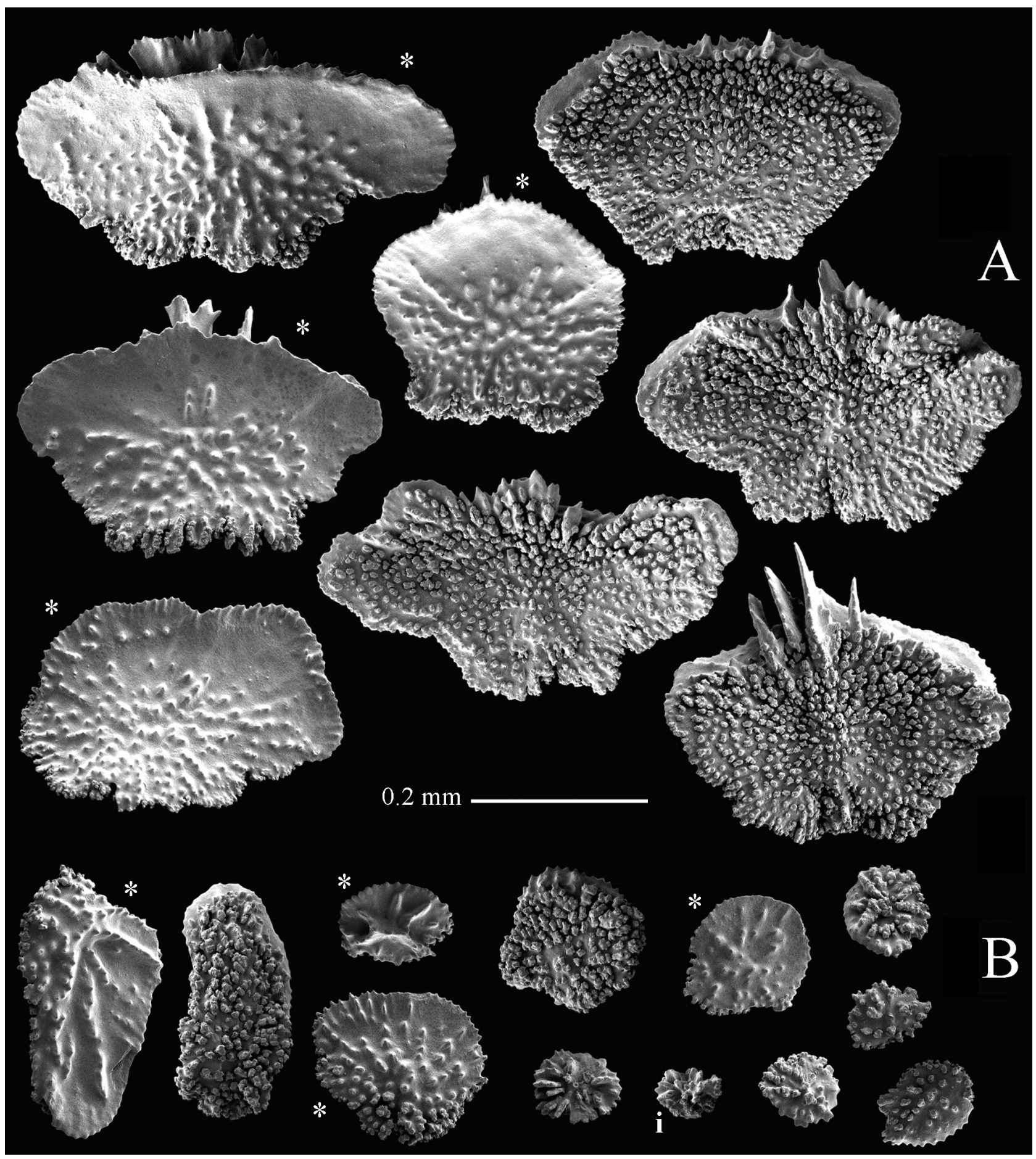

FIG. 6. - Thouarella regularis (Wright and Studer, 1889), lectotype (NHMUK 1889.5.27.60): A, body scales; B, coenenchymal sclerites. [* outer surface view; i sclerite from inner layer].

Variability. The paralectotypes and additional material are pinnate colonies branched in one plane, branchlets ramified up to the second order and up to $9 \mathrm{~cm}$ long. The maximum height and width of the colonies is $25 \mathrm{~cm}$ and $13 \mathrm{~cm}$, both measurements belonging to the lectotype. The number of polyps per centimetre can vary from 7 to 14 . The polyps' shape, their arrangement and the shape of the sclerites are similar to those in the lectotype.

Geographical and bathymetrical distribution. Thouarella regularis is known from Inaccessible and Nightingale Island from the archipelago of Tristan da Cunha, and from Saint Helena, SubAntarctica, between 137 and $658 \mathrm{~m}$ in depth. 


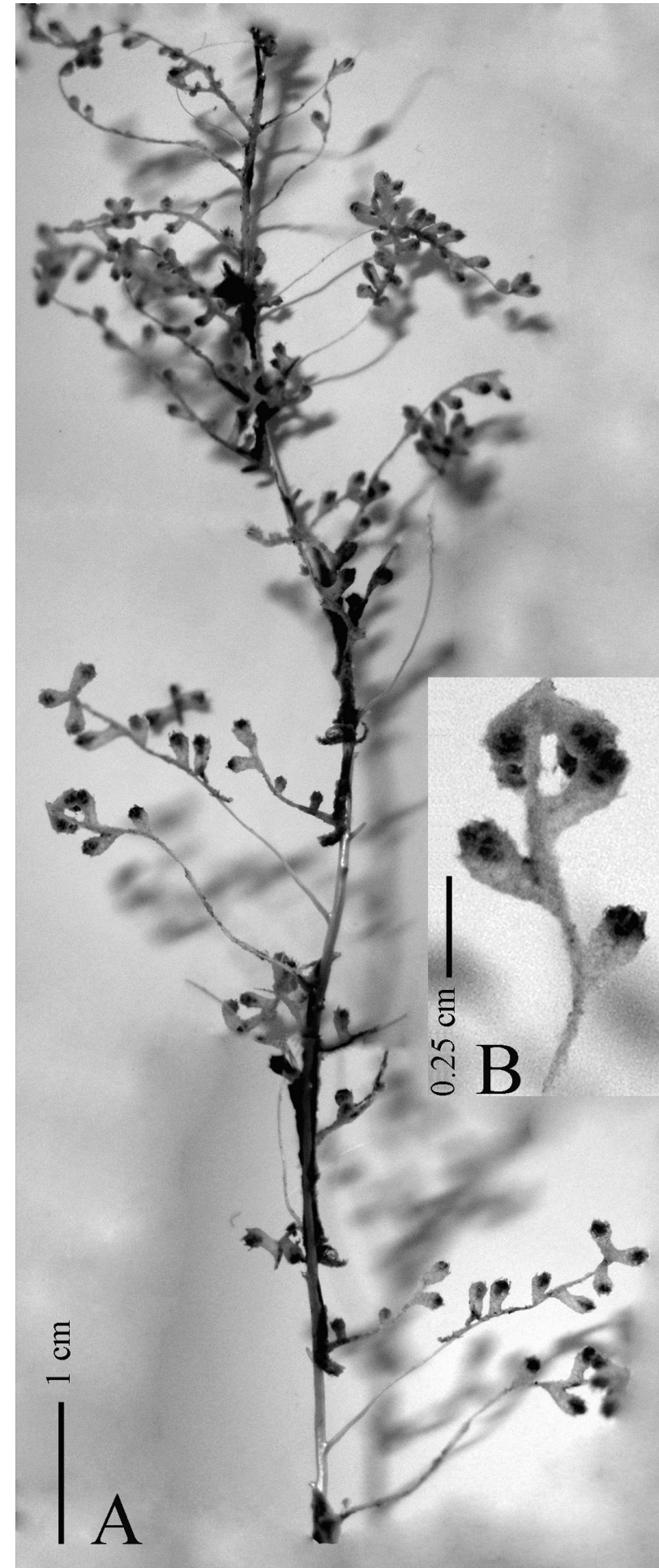

FIG. 7. - Thouarella dispersa Kükenthal, 1912, holotype (ZMB Cni 5468): A, whole colony; B, detail of branchlet. [Photo: Carsten Lueter, ZMB, Berlin].

Thouarella dispersa Kükenthal, 1912 (Figs. 7-9)

Thouarella dispersa Kükenthal, 1912: 307-309; pl. 20, fig. 4; text Figs. 13-16.
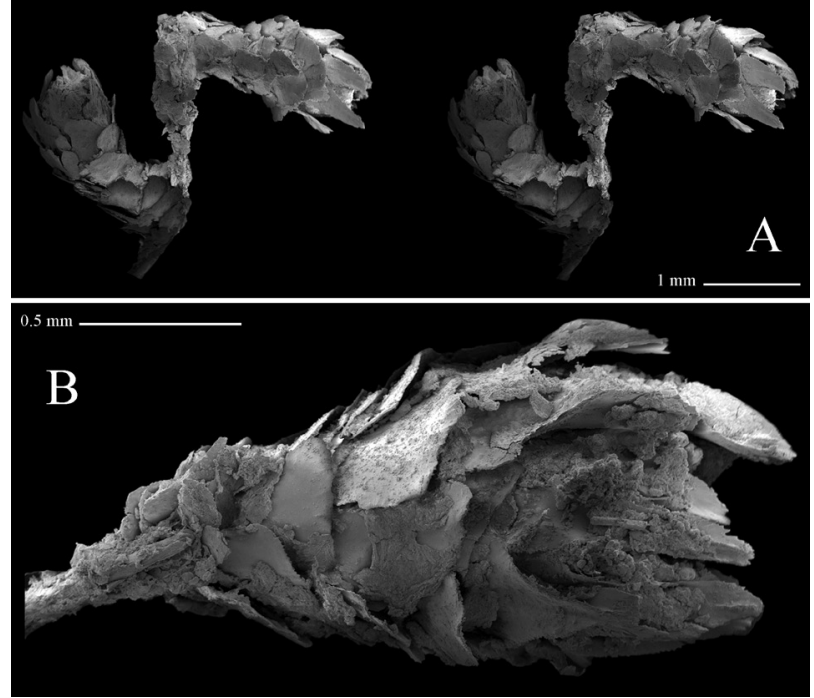

FIG. 8. - Thouarella dispersa Kükenthal, 1912, holotype (ZMB Cni 5468): A, polyps on lateral view, stereo pair; B, polyp on lateroadaxial view.

Thouarella (Amphilaphis) dispersa, Kükenthal, 1915: 149. Kükenthal 1919: 411-412; pl. 31, Fig. 11. Kükenthal 1924: 290-291.

Amphilaphis dispersa, Cairns and Bayer, 2009: 28.

Examined material. Holotype: ZMB Cni 5468, Deutsche SüdpolarExpedition, Antarctica, $2450 \mathrm{~m}$ depth, 1 March 1903.

Description of the holotype. Slender bottlebrush colony (Fig. 7A), $18 \mathrm{~cm}$ in high and $5.3 \mathrm{~cm}$ wide. Simple slender branchlets, up to $3.5 \mathrm{~cm}$ long, sparsely arranged, 4 branchlets per centimetre, in acute angles upward to stem. Axis pearl in colour, slender and graceful, without holdfast. Basal axis diameter $1.6 \mathrm{~mm}$.

Polyps (Fig. 7B) inclined upward to branchlet, singly placed and occasionally biserial, present also on main stem, 6 polyps per $\mathrm{cm}$ arranged on 2 sides. Polyps (Fig. 8) relatively elongated, funnel-shaped, up to $1.9 \mathrm{~mm}$ tall and $0.8-1 \mathrm{~mm}$ maximum diameter, with a conical operculum. Polyp body with 8 rows of scales, 5 in each abaxial row, and 3-4 smaller scales in each adaxial row (Fig. 8B).

Eight opercular scales (Fig. 9A), 0.64-0.99×0.22$0.40 \mathrm{~mm}$, long tongue-shaped wider basally, rounded apex and bilobed base. Proximal inner surface tuberculate covering up to half of the length; sclerites convex, with longitudinal ridges forming an incipient distal keel. Outer surface smooth or radially granular. Free margin finely serrated.

Eight marginal scales (Fig. 9B), 0.63-0.85 $\times 0.32-$ $0.52 \mathrm{~mm}$, pentagonal-shaped with acute apex. Proximal inner surface tuberculate covering about half of the length, multi keeled distally. Outer surface almost radially granular. Basal margin with irregular processes, free margin finely serrated.

Body scales (Fig. 9C) roughly round in shape, 0.21-0.53 mm maximum length. Inner surface almost completely tuberculate, outer surface almost smooth with some granules. Basal margin with tuberculate processes, free margin finely serrated. 


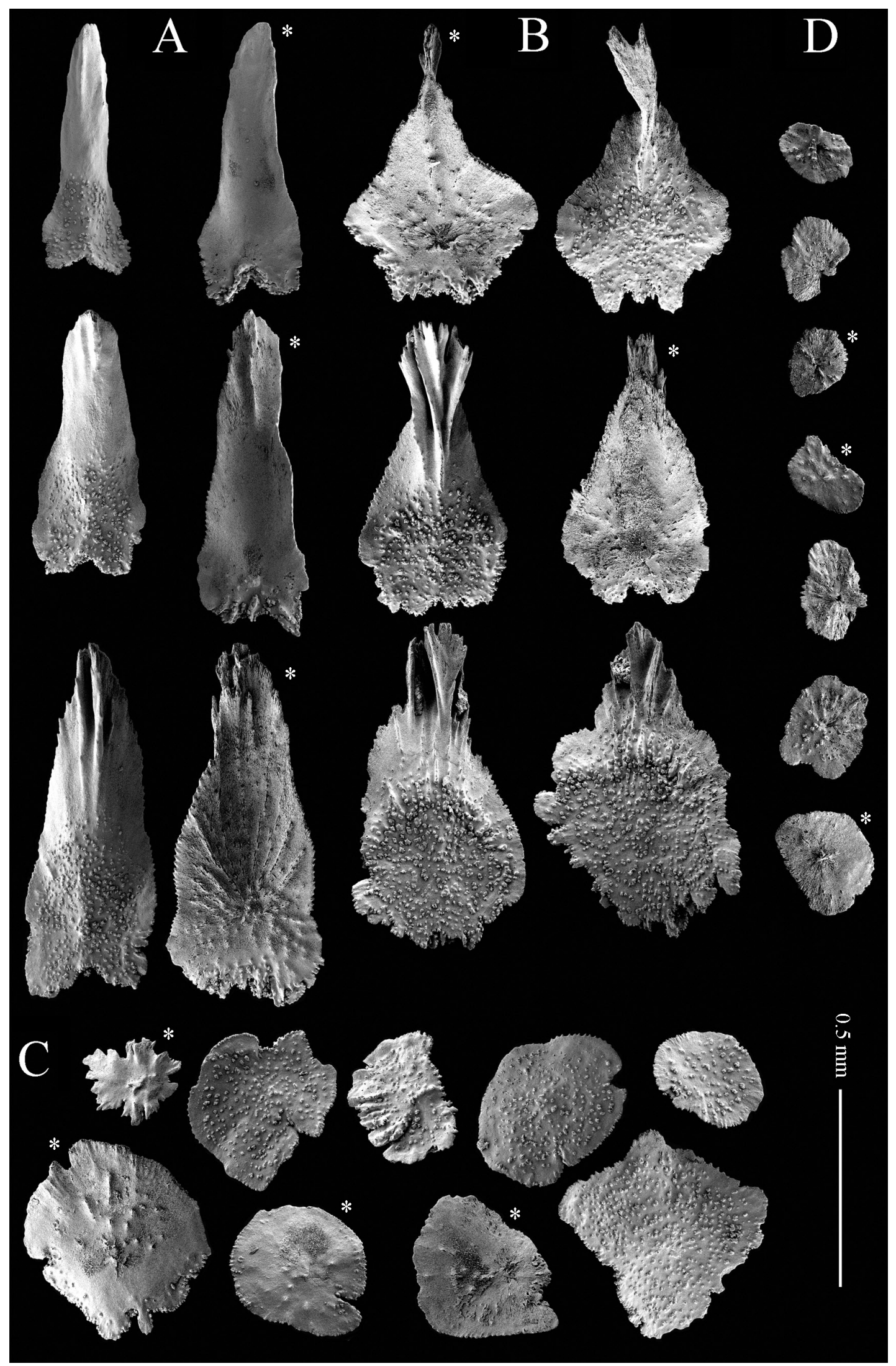

FIG. 9. - Thouarella dispersa Kükenthal, 1912, holotype (ZMB Cni 5468): A, opercular scales; B, marginal scales; C, body scales; D, coenenchymal sclerites. [* outer surface view]. 


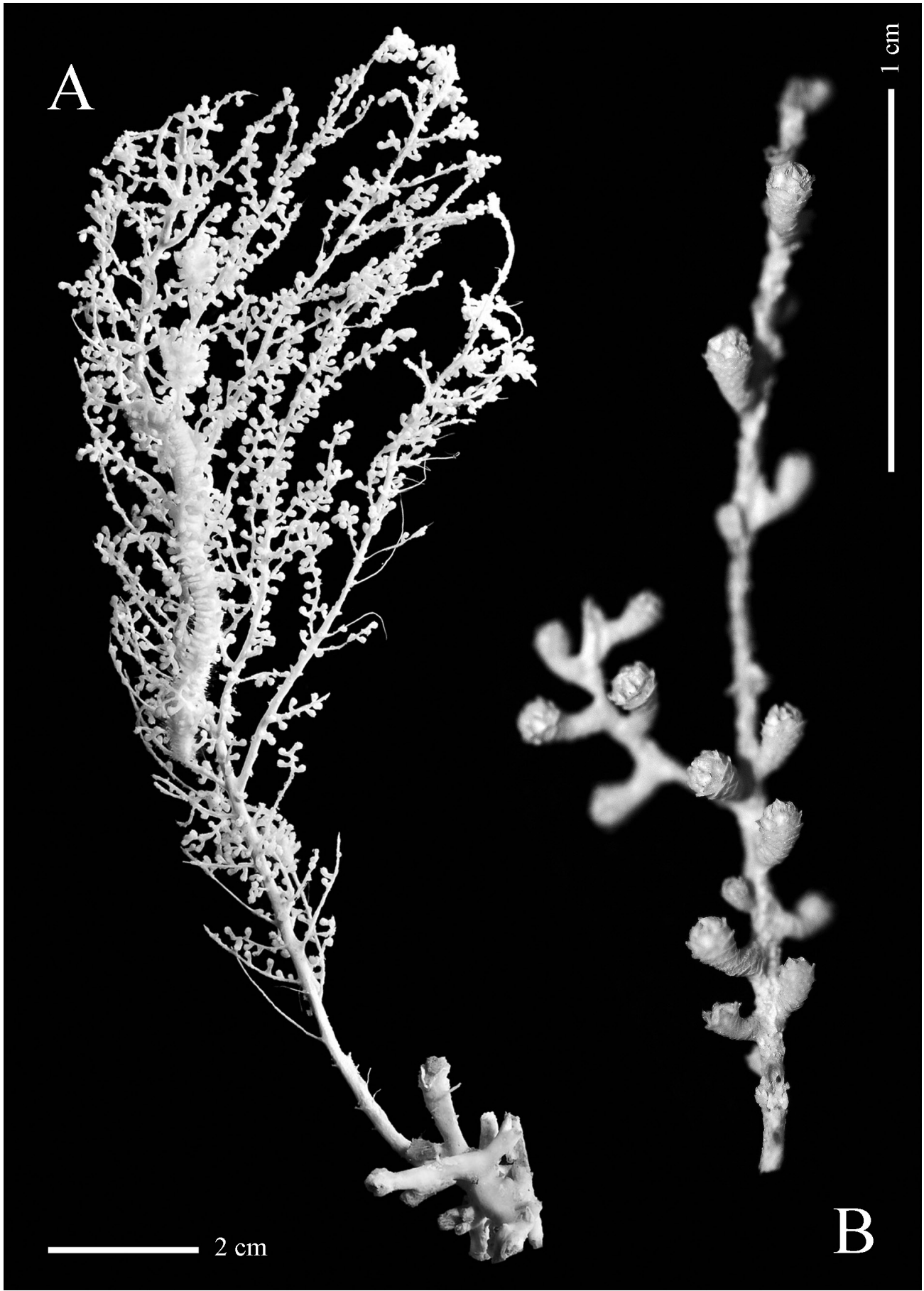

FIG. 10. - Thouarella grandiflora Kükenthal, 1912: A, holotype (ZMB Cni 5469), whole colony, [photo: Carola Radken, ZMB, Berlin]; B, paralectotype (MPUW 44), detail of branchlet.

Coenenchymal sclerites (Fig. 9D) round in shape, $0.12-0.28 \mathrm{~mm}$ maximum length. Inner surface with scattered tubercles, outer surface slightly smooth with some granules, margin finely serrated.

Geographical and bathymetrical distribution. Thouarella dispersa is only known from the type locality, Antarctica, at a depth of $2450 \mathrm{~m}$.
Thouarella grandiflora Kükenthal, 1912

(Figs. 10-14)

Thouarella grandiflora Kükenthal, 1912: 309-310; pl. 21, Fig. 6; text Figs. 17-20.

Thouarella (Amphilaphis) grandiflora, Kükenthal, 1915: 149. Kükenthal 1919: 413; text Fig. 180. Kükenthal 1924: 291. Amphilaphis grandiflora, Cairns and Bayer, 2009: 28. 

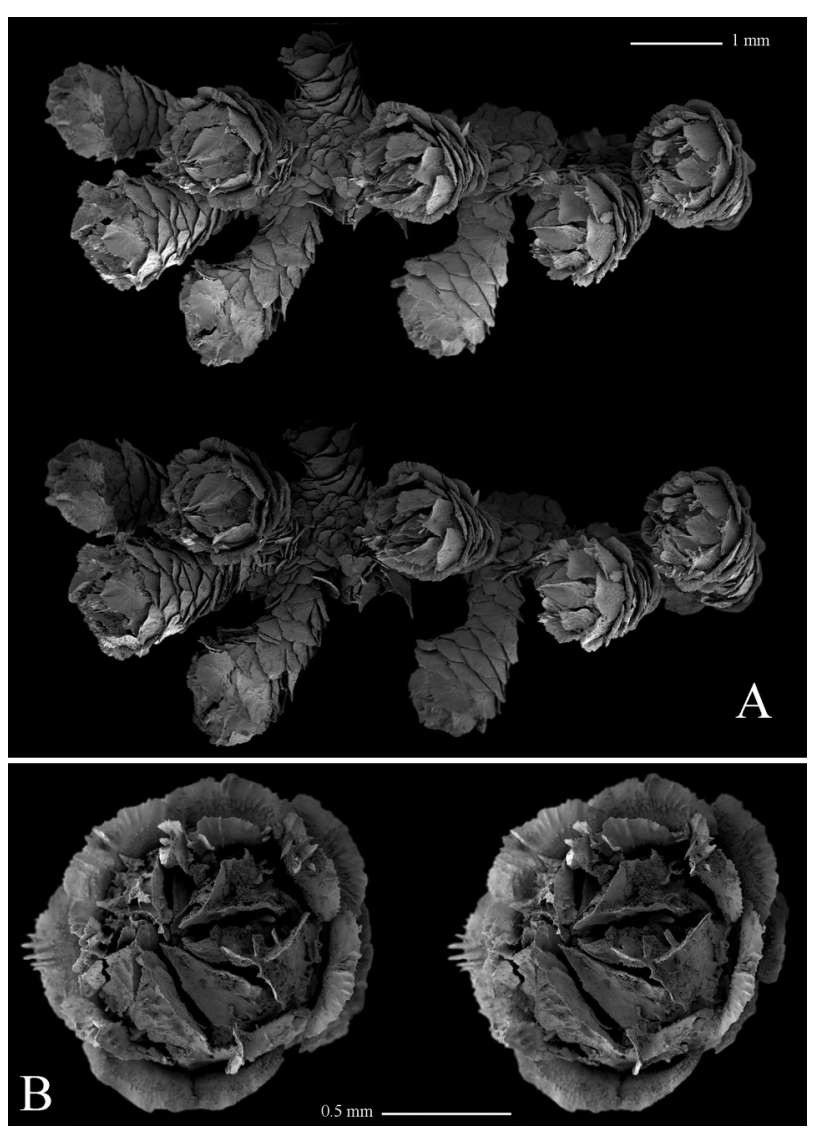

Fig. 11. - Thouarella grandiflora Kükenthal, 1912, holotype (MPUW 44): A, detail of branchlet, stereo pair; B, polyp on oral view, stereo pair.

Examined material. Holotype: ZMB Cni 5469 and MPUW 44, Deutsche Südpolar-Expedition, Gauss Station, Antarctica, 385 m. depth, 7 February 1903.

Description of the holotype. Bottlebrush colony (Fig. 10A), $18 \mathrm{~cm}$ high and $7.6 \mathrm{~cm}$ wide. Colony ramified up to the second order with branchlets up to 3.7 $\mathrm{cm}$ long. Axis ochre, holdfast present and attached to a hard substrate, basal axis diameter $2.4 \mathrm{~mm}$. Polyps almost perpendicular but slightly curved upward to stem and branchlets (Fig. 10B, 11A), singly placed, arranged in spirals, spaced about 8 polyps per $\mathrm{cm}$. Polyps club-shaped (Fig.11, 12), about 1.5-2.4 mm tall and $0.4-1.2 \mathrm{~mm}$ greatest diameter, with body scales in 8 longitudinal rows, adaxial scales reduced in size and number; 6-8 in each abaxial row (Fig. 12B) but 4 smaller scales in each adaxial row (Fig. 12C).

Eight opercular scales (Fig. 11B, 13A), 0.42$0.58 \times 0.15-0.29 \mathrm{~mm}$, arrow-head-shaped with an acute apex and a bilobed base. Proximal inner surface sparsely tuberculate up to half of scale length; distal part with strong-ridged keel. Outer surface radially granular forming ridges, concave surface deeper distally. Free margin finely serrated, basal margin with tuberculate processes.

Eight marginal scales (Fig. 13B), pentagonalshaped, $0.44-0.54 \times 0.31-0.46 \mathrm{~mm}$. Inner surface sparsely tuberculate covering up to $75 \%$ of the scale, with middle longitudinal prominent multi-keels distally. Outer surface radially granular, forming ridges. Free margin finely serrated, basal margin with irregular processes.

Body wall scales (Fig. 14A) fan-shaped, 0.26$0.48 \times 0.26-0.56 \mathrm{~mm}$. Inner surface almost completely sparsely tuberculate with or without crests centrally placed on the distal border. Outer surface granular. Free margin finely serrated, basal margin with irregular processes. Coenenchymal sclerites (Fig. 14B) round or oval-shaped, 0.18-0.47 mm maximum length. Inner surface completely tuberculate, outer surface with few granules, free margin finely serrated, proximal border with tubercles.

Geographical and bathymetrical distribution. Thouarella grandiflora is only known from the holotype locality of Gauss Station, Antarctica at a depth of $385 \mathrm{~m}$.
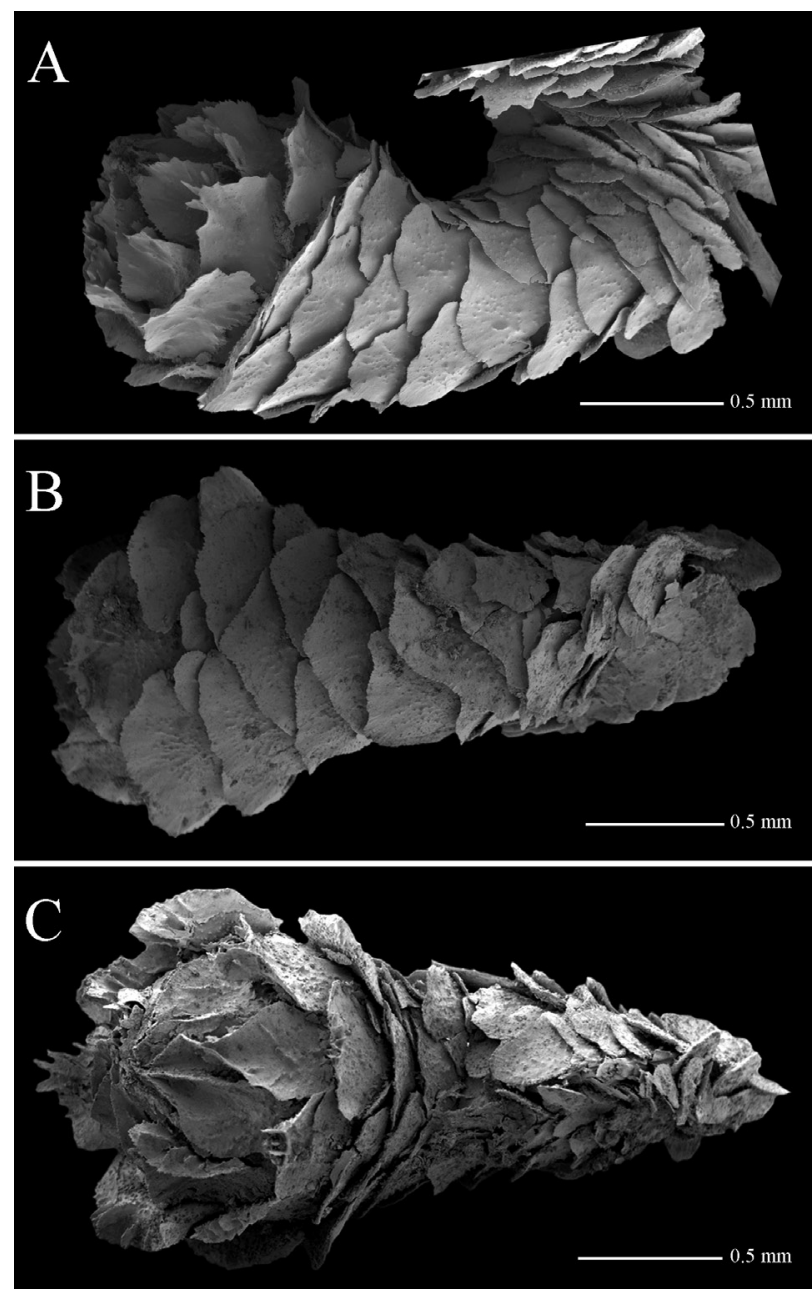

FIG. 12. - Thouarella grandiflora Kükenthal, 1912: A, holotype (ZMB Cni 5469), polyp on lateral view; B, paralectotype (MPUW 44 ), polyp on abaxial view; C, paralectotype (MPUW 44), polyp on adaxial view. 


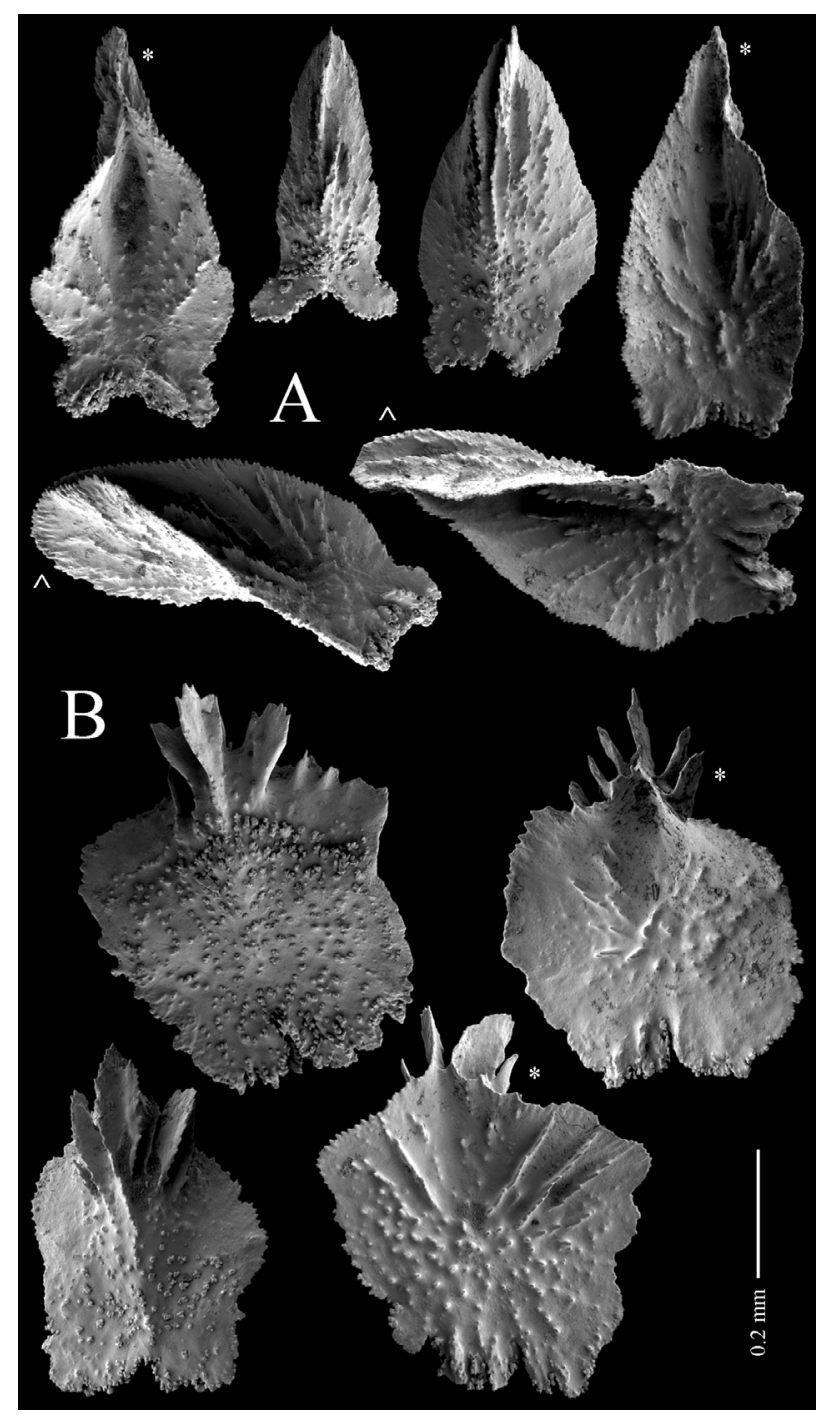

FIG. 13. - Thouarella grandiflora Kükenthal, 1912, holotype (MPUW 44): A, opercular scales; B, marginal scales. [* outer surface view; ^ lateral view].

\section{Thouarella vitjaz n. sp.}

(Figs. 15-17)

Thouarella abietina, Pasternak, 1981: 49-50.

Examined material. Holotype: IORAS IV-9-Alc-010-002, RV Vitjaz, cruise 48 , stn $6275,12^{\circ} 12^{\prime} \mathrm{N} 179^{\circ} 49^{\prime} \mathrm{E}, 6400 \mathrm{~m}$ depth, 2 branchlets. Paratype: IORAS IV-9-Alc-010-001, RV Vitjaz, cruise 48, stn 6265, 26 $6^{\circ} 56.1^{\prime} \mathrm{N} 178^{\circ} 38^{\prime} \mathrm{E}, 3200 \mathrm{~m}$ depth, 23 May 1970, 2 fragments.

Description of the holotype. Two small, delicate dry branchlets, 1.3 and $1.4 \mathrm{~cm}$ long (Fig. 15A). Polyps small, curved upward to branchlets at 45 (Fig. 15B), placed in pairs about $0.5 \mathrm{~mm}$ apart, 7 pairs per $\mathrm{cm}$. They are trumpet-shaped (Fig. 16), about $0.74-1.1 \mathrm{~mm}$ tall and $0.39-0.57 \mathrm{~mm}$ greatest diameter with a low operculum and body scales in 8 longitudinal rows . Each abaxial row has 5-6 scales (Fig. 16A) and 3 in each adaxial row (Fig. 16B).

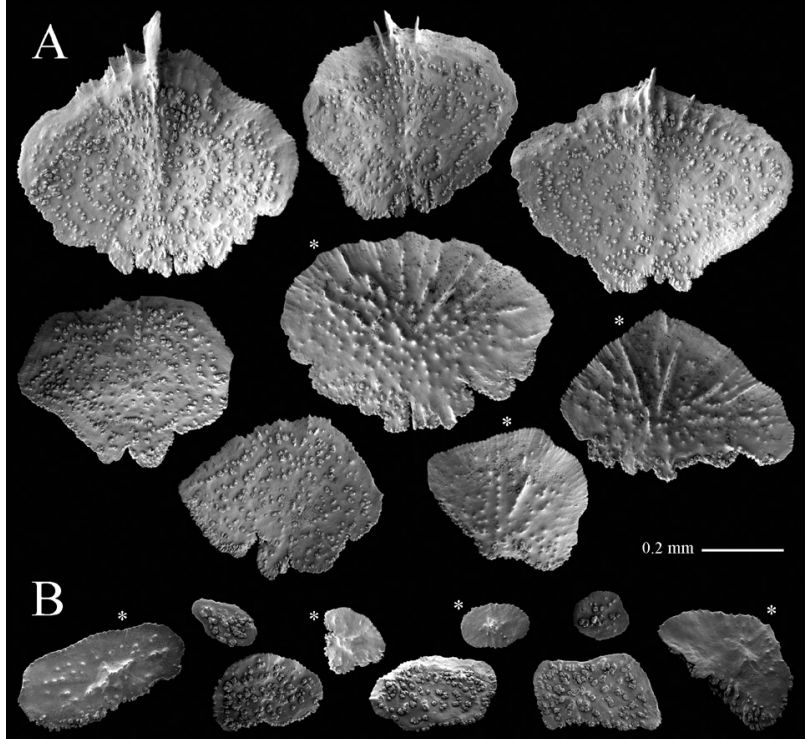

FIG. 14. - Thouarella grandiflora Kükenthal, 1912, holotype (MPUW 44): A, body scales; B, coenenchymal sclerites. [* outer surface view].
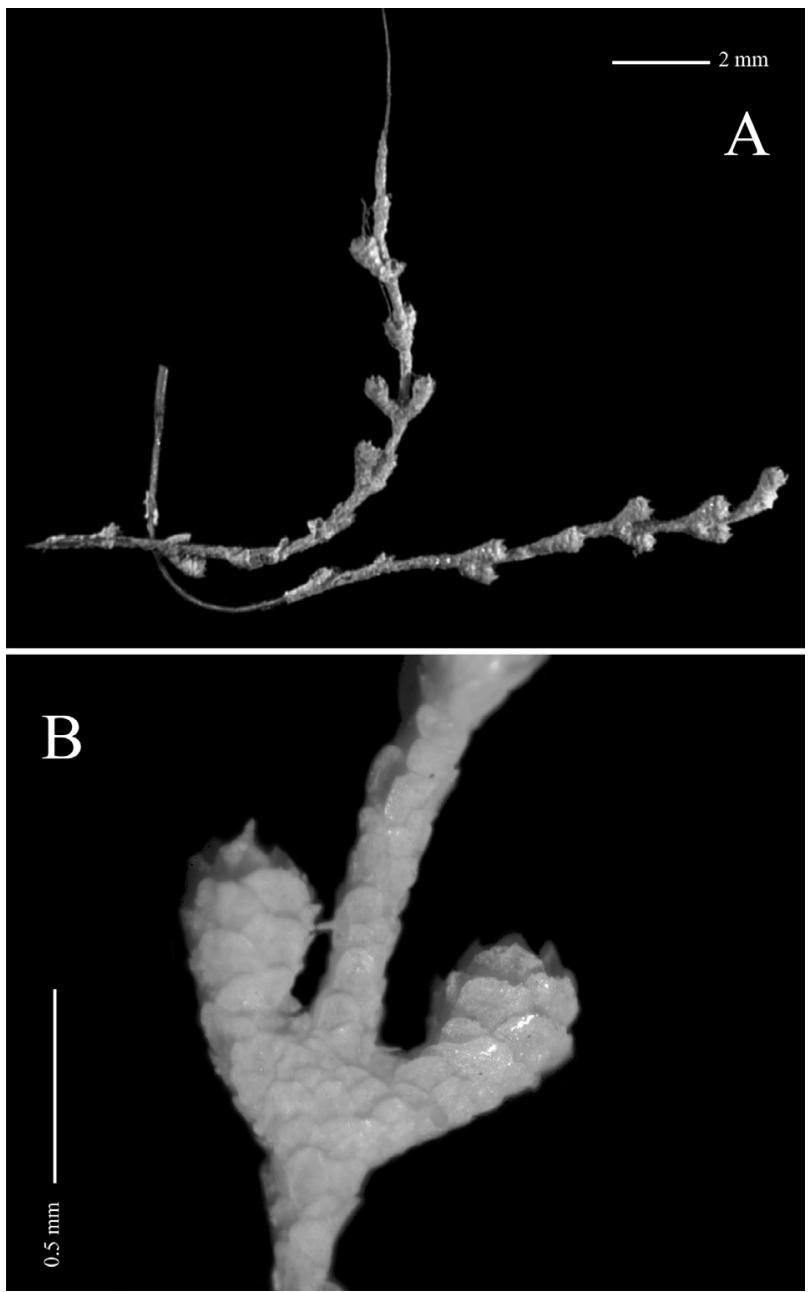

FIG. 15. - Thouarella vitjaz n. sp., holotype (IORAS IV-9Alc-010-002): A, detail of branchlet; B, detail of a whorl of two polyps. 

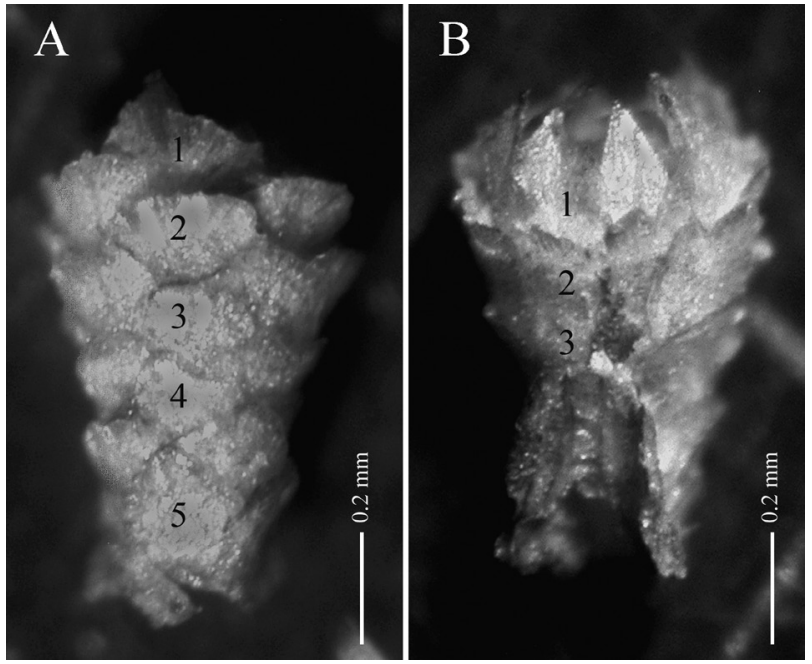

FIG. 16. - Thouarella vitjaz n. sp., holotype (IORAS IV-9Alc-010-002): A, polyp on abaxial view; B, polyp on adaxial view.

Eight opercular scales (Fig. 17A), 0.14-0.21×0.06$0.11 \mathrm{~mm}$, tongue-shaped. Proximal inner surface tuberculate covering up to a third of the length, distal surface with several longitudinal ridges. Outer surface granular, free margin finely serrated.

Eight marginal scales (Fig. 17B), $0.23-0.27 \mathrm{~mm}$ tall and $0.12-0.16 \mathrm{~mm}$ wide, lancet-shaped with an acute apex; adaxials reduced. Inner proximal surface tuberculate, covering less than a half of their length, distal portion from smooth to ridged, with a modest medial keel. Outer surface granular. Basal margin with small granular processes, free margin finely serrated.

Upper cycle of body scales, or submarginals, (Fig. 17C: sms), roughly triangular-shaped, $0.25-0.30 \mathrm{~mm}$ tall and $0.18-0.24 \mathrm{~mm}$ wide. Inner proximal surface tuberculate, covering up to half of the length, long ridges distally and a modest medial keel. Remaining body scales (Fig. 17C), round to fan-shaped, 0.11$0.24 \mathrm{~mm}$ tall and $0.16-0.28 \mathrm{~mm}$ wide. Inner surface tuberculate covering at least $75 \%$ of the scale, with long radial ridges distally decreasing in size in the more basal scales. Outer surface granular. Basal margin with small granular processes, free margin finely serrated.

Coenenchymal scales (Fig. 17D) round to ovalshaped, 0.07-0.20 $\mathrm{mm}$ maximum length. Inner surface tuberculate, outer surface granular. Basal margin with small granular processes, free margin finely serrated.

Variability. The paratype consists of 2 small dry fragments, of which the largest is $1.8 \mathrm{~cm}$ long. The shortest is a branchlet of $1.2 \mathrm{~cm}$. The polyps' shape and arrangement and the shape of the sclerites are similar to those in the holotype.

Geographical and bathymetrical distribution. Thouarella vitjaz $\mathrm{n}$. $\mathrm{sp}$. is only know from the middle of the northern Pacific Ocean, between the Marshall Islands and Johnston Atoll and from the south west of
Green Island, the Midway Islands, the Hawaiian archipelago, Pacific Ocean, at 3200 and $6400 \mathrm{~m}$ depth.

Etymology. The species name, vitjaz, refers to the Soviet Union's research vessel "Витязь" (=knight), from which the new species was collected. The name is treated as a noun in apposition.

\section{Remarks on the species transferred to the genus Thouarella}

The genus Amphilaphis was originally erected by Wright and Studer (1889: 71), for Amphilaphis regularis, the type species. Subsequently, Kükenthal (1912: 307) included this species in the genus Thouarella, giving as reasons the shape of the polyps, the number of scales in each longitudinal abaxial row, and mainly the biserial arrangement of the branchlets which he had found in other Thouarella species he described (e.g. Thouarella flabellata Kükenthal, 1907), although the colony shape was considered by Wright and Studer as a generic character to differentiate Thouarella (bottlebrush) from Amphilaphis (fan-shaped). However, a few years later, Kükenthal considered Amphilaphis to be a subgenus of Thouarella (Kükenthal, 1915) because it has 8 well-organized rows of scales from the distal to the basal part of the polyp, and because of the long and slender appearance of the branchlets. The last revisionary contribution concerning the family Primnoidae (Cairns and Bayer 2009) treated Amphilaphis at the generic level, distinguishing it from other primnoid genera because of the equal size of the 8 rows of body scales and the pinnate branching pattern, but they did not illustrate the adaxial side of the polyps, thus attributing an equal size of body scales by mistake.

As a result of our research, we consider it more appropriate to include the species Amphilaphis regularis in the genus Thouarella for the following reasons: 1) its adaxial body scales are reduced (Fig. 4A); 2) its marginal scales fold over the operculars in an indented way (Fig. 4); 3) its pinnate branching pattern is included among the current variations of colony form for that genus; and 4) its biserial polyp arrangement is also found in other Thouarella species. However, that transfer of Amphilaphis regularis to Thouarella produces a junior secondary homonym of $T$. regularis Kükenthal, 1907 that must be treated as invalid as both species are considered congeneric and thus replaced by a substitute name (International Commission on Zoological Nomenclature 1999). In the revision of the genus Thouarella by M. Taylor et al. (submitted, pers. comm.), T. regularis Kükenthal, 1907 would be synonymized with T. laxa Versluys, 1906. Furthermore, T. regularis should be included in the subgenus Epithouarella due to the lack of a thorn in the marginal scales (Kükenthal 1915, Cairns and Bayer 2009). As a consequence of the removal of the type species from genus Amphilaphis, the genus should no longer be considered valid. 


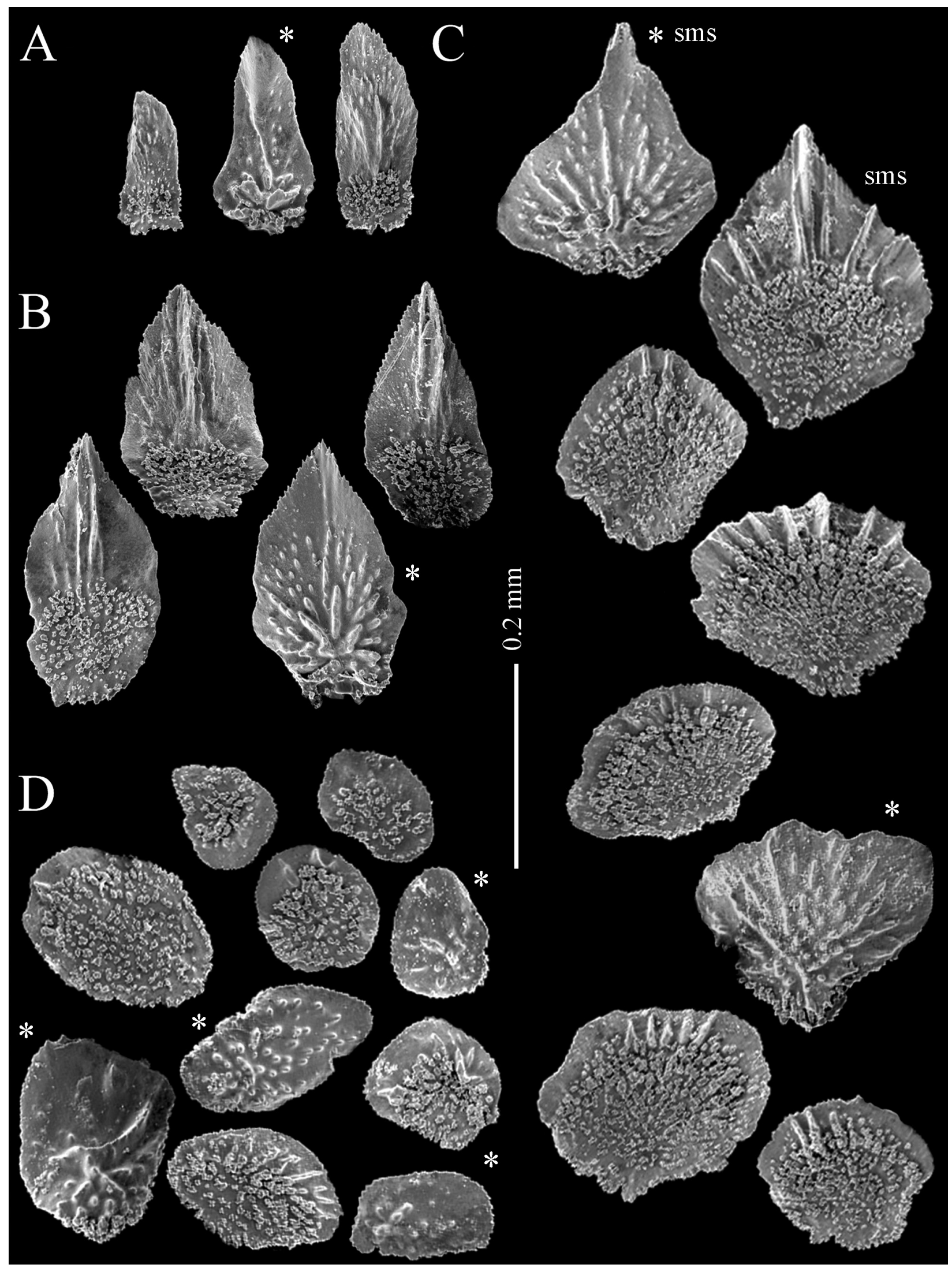

FIG. 17. - Thouarella vitjaz n. sp., holotype (IORAS IV-9-Alc-010-002): A, opercular scales; B, marginal scales; C, body scales; D, coenenchymal sclerites. [*outer surface view; sms=submarginal scales]. 


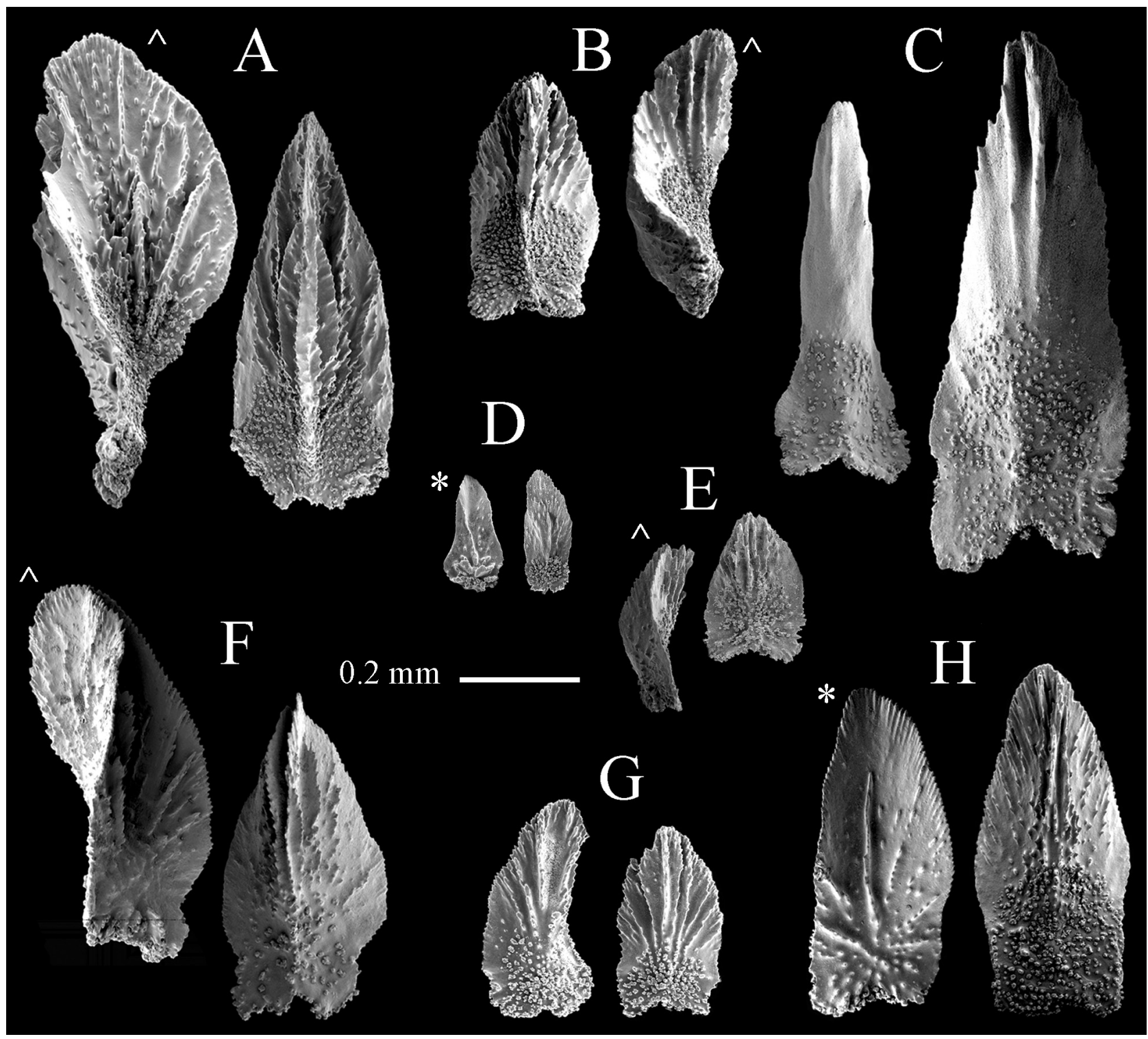

FIG. 18. - Comparison of opercular scales from species included in subgenus Epithouarella: A, Thouarella viridis Zapata-Guardiola and López-González, 2010, holotype (ZIZMH C11744); B, T. regularis (Wright and Studer, 1889), lectotype (BMNH 1889.5.27.60); C, T. dispersa Kükenthal, 1912, holotype (ZMB Cni 5468); D, T. vitjaz sp.nov., type IORAS IV-9-Alc-010-002); E, T. crenelata Kükenthal, 1907, syntype (ZMB Cni 6081); F, T. grandiflora Kükenthal, 1912, holotype (MPUW 44); G, T. chilensis Kükenthal, 1908, type fragment (ZMB

Cni 6079); H, T. affinis Wright and Studer, 1889, holotype (BMNH 1889.5.27.44). [*outer surface view; ^ lateral view].

As a consequence, the most plausible proposal now is to assign the species Thouarella dispersa and T. grandiflora, which were originally described by Kükenthal in 1912 but later transferred by him to Amphilaphis (as a subgenus of Thouarella) in 1915, to the genus Thouarella. The reduction in size and number of the adaxial body scales (Fig. 12C, 16B), and the presence of 8 keeled marginal scales (Figs.9B, 13B, 17B) aligned with the operculars and folding over them (Figs. 8B, 11B), are characters supporting the inclusion of both Thouarella dispersa, T. grandiflora (Kükenthal 1912: 307) and T. vitjaz n. sp. in the genus Thouarella. Furthermore, the lack of a well-developed thorn on the marginal scales allows us to include these species in the subgenus Epithouarella.
Although there are currently 4 species included in the subgenus Epithouarella: Thouarella affinis Wright and Studer, 1889, T. crenelata Kükenthal, 1907, T. chilensis Kükenthal, 1908 and T. viridis Zapata-Guardiola and López-González, 2010, the species here redescribed are clearly distinguishable.

Considering the few data provided by Pasternak (1981), Thouarella vitjaz n. sp. seems to be ramified in one plane. In the subgenus Epithouarella, only $T$. regularis and $T$. vitjaz n. sp. have colonies in one plane, while the other species in the subgenus have bottlebrush colonies. However, the polyps of $T$. regularis are placed alternately in the branchlets, while they are in pairs in the new species. Other differences can also be 
found in the structure of the sclerites (see Figs. 18B, $\mathrm{D}$ and 19B, D in this paper), and the development of the keel on the operculars and marginals is especially noticeable.

Thouarella dispersa has 5 scales in each longitudinal abaxial row, while the other Epithouarella species have between 6 and 10 scales. Furthermore, $T$. dispersa has a low density of polyps per $\mathrm{cm}$, which is similar only to T. affinis, but the opercular and marginal scales of the two species are completely different. In $T$. dispersa the operculars are larger, their inner distal surface is quite smooth and the proximal warts are distant (Fig. 18C), while in T. affinis the operculars are smaller, their distal inner surface is covered by prickly granules and the proximal warts are closer (Fig. $18 \mathrm{H}$ ). The marginal scales of $T$. dispersa are triangular-shaped with a strong multi-keel on the inner surface (Fig. 19C), while in T. affinis the marginals are rhomboidal-shaped with a thin projection like a small thorn (Fig. 19H).

Thouarella grandiflora is comparable with $T$. viridis because the two species share some characters, such as the number of scales in the abaxial row, the strong keel present on the inner surface of the opercular scales and the similar polyp size. However, the two species are distinguished by the size of the opercular scales, larger in $T$. viridis than in T. grandiflora; by the density of polyps on the branchlets, 14-15 polyps per $\mathrm{cm}$ in T. viridis and only 8 per $\mathrm{cm}$ in $T$. grandiflora; and by the ornamentation on the inner surface of the scales (in $T$. viridis the proximal warts are more crowded (Fig. 18A) than in T. grandiflora (Fig. 18F)). In addition, the ornamentation on their marginal scales is also different, those of $T$. viridis having a small blunt

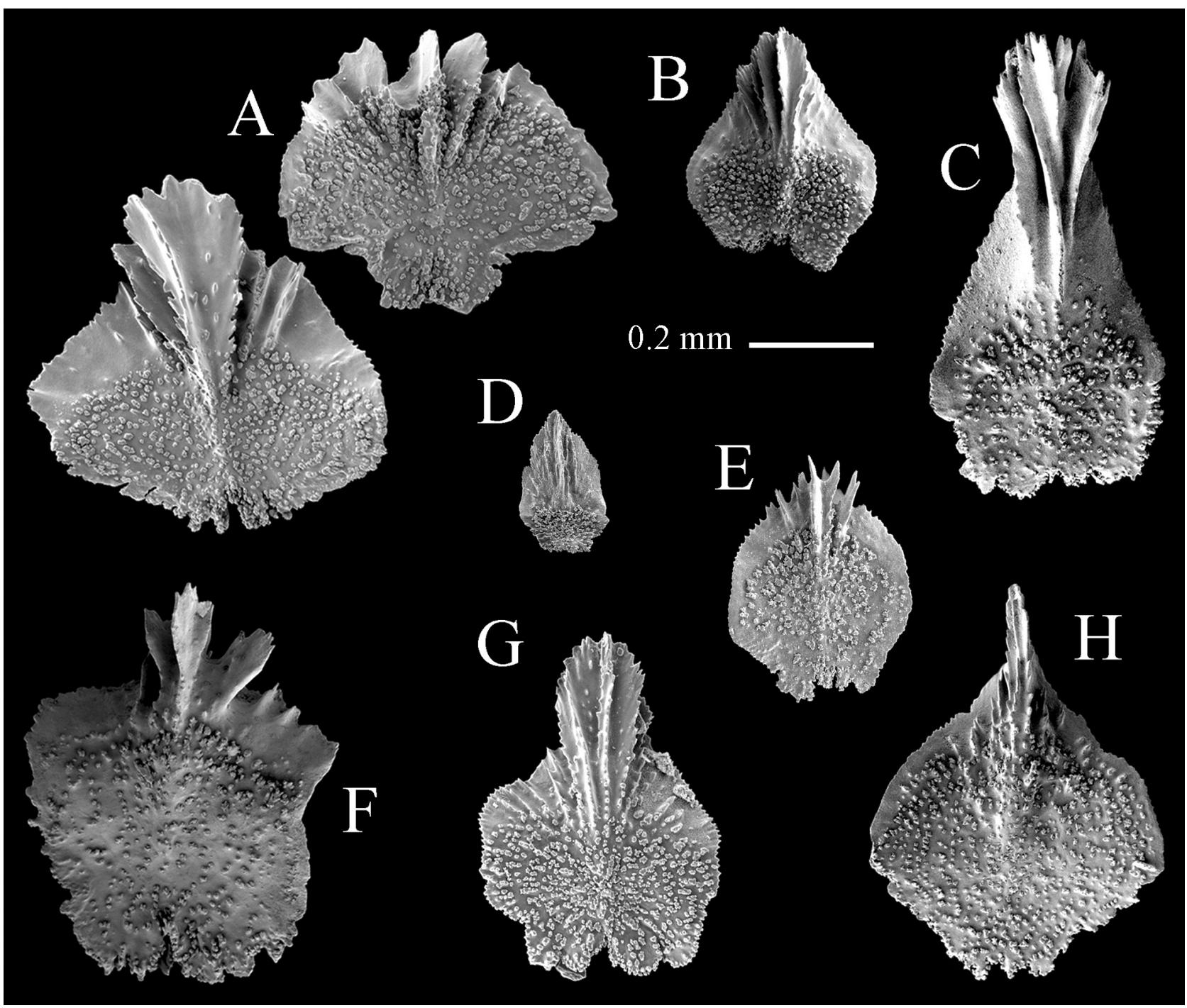

FIG. 19. - Comparison of marginal scales, inner surface view, from species included in subgenus Epithouarella: A, Thouarella viridis Zapata-Guardiola and López-González, 2010, holotype (ZIZMH C11744); B, T. regularis (Wright and Studer, 1889), lectotype (BMNH 1889.5.27.60); C, T. dispersa Kükenthal, 1912, holotype (ZMB Cni 5468); D, T. vitjaz sp.nov., type (IORAS IV-9-Alc-010-002); E, T. crenelata Kükenthal, 1907, syntype (ZMB Cni 6081); F, T. grandiflora Kükenthal, 1912, holotype (MPUW 44); G, T. chilensis Kükenthal, 1908, type fragment (ZMB Cni 6079); H, T. affinis Wright and Studer, 1889, holotype (BMNH 1889.5.27.44). [*outer surface view]. 
spine or short medial ridges (Fig. 19A) and those of $T$. grandiflora having a multi-keel (Fig. 19F).

Thouarella regularis should be compared with $T$. crenelata and T. chilensis as they have 8 scales in the abaxial row and an incipient keel consisting of numerous longitudinal ridges (Fig. 18B,E,G) on the inner surface of the opercular scales. However, the operculars are larger in $T$. regularis than in the other 2 species. Furthermore, the marginal scales in T. chilensis are strongly ornamented and larger than in T. crenelata and T. regularis (Fig. 19B,E,G); the tendency in T. crenelata is to have fine longitudinal apical crests, whereas in $T$. regularis it is to have a prominent distal keel with lateral ridges. In addition, in $T$. crenelata the polyps are more perpendicular to the branchlets than in $T$. regularis, where they are inclined upward to the branchlets (compare Kükenthal 1919: Fig. 70 and Fig. $3 \mathrm{~A}$, present work).

However, in the revision of genus Thouarella by M. Taylor et al. (submitted, pers. comm.) the different subgenera will surely be reconsidered.

Thouarella biserialis (Nutting, 1908) was originally described in the genus Amphilaphis but immediately afterwards it was included in the genus $T h$ ouarella by Kinoshita (1908a). In the recent generic revision of Primnoidae by Cairns and Bayer (2009), it was again placed in the genus Amphilaphis. However, Cairns placed it back in the genus Thouarella in 2010. During this present work we also had the opportunity to examine the type of Thouarella biserialis (Nutting, 1908), which consists of just one small and poorly preserved branch fragment, and this led us to agree with Kinoshita (1908a) and Cairns (2010) in the reassignation of this species to the genus Thouarella because of the reduction of its adaxial body scales and the presence of a keel on marginal scales that fold over the operculars. Thouarella biserialis seems to have a dichotomous branching pattern, which in combination with the arrangement of polyps in pairs places the species in the subgenus Diplocalyptra Kinoshita, 1908, as suggested by Cairns (2010). Kinoshita (1908b: 60) already noticed the similarities of Thouarella biserialis with those attributable to Diplocalyptra species and thus including it in this subgenus. He pointed out that Thouarella coronata (Kinoshita, 1908b) and T. parva (Kinoshita, 1908b) are clearly differentiated from $T$. biserialis by the arrangement and orientation of the polyps (in whorls of 3 or 4 and perpendicular in T. coronata, but in pairs and curved upward in T. biserialis) and by the total number of longitudinal body row scales (these being 8 in T. parva and 4 in T. biserialis). Moreover, the density of whorls or pairs per centimetre is also different in the two species, being 7 in $T$. coronata, and 5 in T. biserialis.

Because of the unknown location of the type material of Thouarella parva, we can only compare it with T. biserialis through the original description. Kinoshita (1908b) distinguished the two species by the lower number of longitudinal rows of body wall scales in $T$. biserialis. In the original description of $T$. biserialis (Nutting, 1908) we can read "The calyx walls are covered with... and usually 4 longitudinal rows". However, a study of the type material reveals the presence of 8 longitudinal rows of scales. This contradiction can be explained by the fact that Nutting only counted the abaxial rows and did not include the 2 inner-laterals and the 2 adaxial rows. Furthermore, after comparing the description of $T$. parva with the type of $T$. biserialis we have not been able to find any useful character to distinguish between the species. Since no additional material attributable to T. parva was available we prefer not to propose any synonymy.

\section{Genus Plumarella Gray, 1870}

Diagnosis. Primnoidae, usually with a uniplanar colony shape and alternately pinnate branching, may also be dichotomously branched and bottlebrush in shape. Polyps placed in an alternate biserial arrangement, in pairs or without order on all sides of branchlets. Polyps completely covered by 8 longitudinal rows of body scales, adaxials may be reduced in number and size. Eight opercular aligned with the 8 marginal scales without folding over them. Marginals variable in shape, their distal edges being spinose, pointed, or straight; inner surface of marginals may be smooth, ridged, or spiny but never keeled.

\section{Subgenus Faxiella n. subgen.}

Diagnosis. Plumarella with a planar colony shape and pinnate branching. Cylindrical-shaped, elongate polyps placed in pairs and curved upward toward the stem and branchlets. Opercular and marginal scales with longitudinal distal ridges. Adaxials smaller and slightly disorganized but always present.

Etymology. The subgeneric name comes from fax, the Latin word for torch, in reference to the shape of the polyps. Gender: feminine.

Type species. Amphilaphis abietina Studer, 1894, here designated.

\section{Plumarella (Faxiella) abietina \\ (Studer, 1894) n. comb.} (Figs. 20-22)

Amphilaphis abietina Studer, 1894: 65. Menneking 1905: 255-260; pl. 8, Fig. 7-8; pl. 9, Fig. 17-20. Versluys 1906: 22. Cairns and Bayer 2009: 28.

Thouarella (Amphilaphis) abietina, Kükenthal, 1915: 149. Kükenthal 1919: 410-411. Kükenthal 1924: 290.

not Thouarella abietina, Pasternak, 1981: 49-50. [=Thouarella vitjaz.n. sp.]

Examined material. Holotype: MCZ 4802, Albatross Expedition, stn Alb-3399, $1^{\circ} 7^{\prime} \mathrm{N} 81^{\circ} 4^{\prime} \mathrm{W}$, west coast of central America to the Galapagos, $3181 \mathrm{~m}$ depth, 1891. 

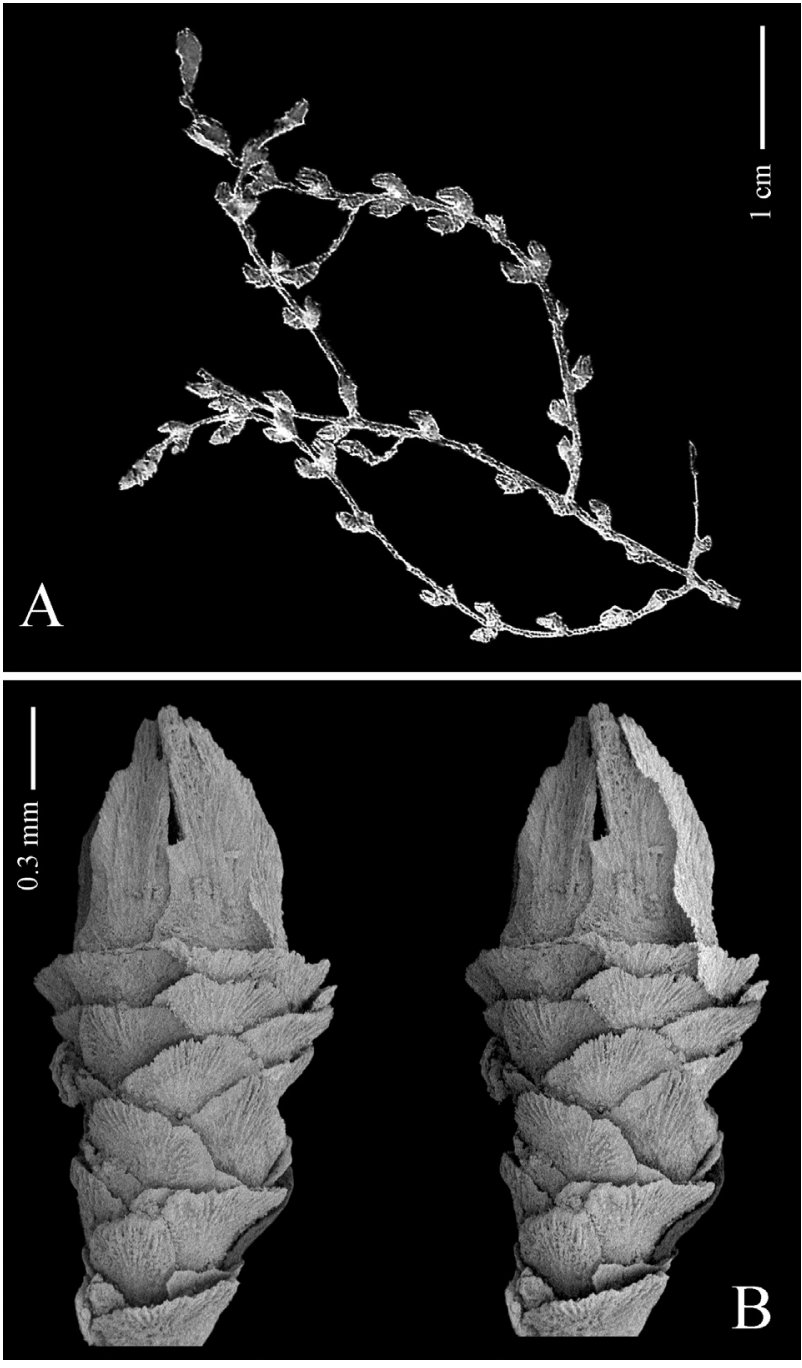

FIG. 20. - Plumarella (Faxiella) abietina (Studer, 1894) n. comb., holotype (MCZ 4802): A, fragment of colony from Menneking, 1905: pl. 8, Fig. 7; B, polyp on abaxial view, stereo pair. [Photo: Stephen D. Cairns, NMNH, Washington].

Description of the holotype. Fragment of colony ramified in one plane (Fig. 20A) $6 \mathrm{~cm}$ in high and 3 $\mathrm{cm}$ wide; ramified up to the third order, with slender branchlets up to $5 \mathrm{~cm}$ long. Axis without holdfast, with a basal diameter of $1 \mathrm{~mm}$. The polyps are curved upward to the stem and branchlets, placed in pairs and sparsely arranged with 2-3 mm between them; 2 pairs of polyps per $\mathrm{cm}$. They are relatively elongate (Fig. 20B, 21A), cylindrical, up to $2.6 \mathrm{~mm}$ tall and $1.0-1.2$ $\mathrm{mm}$ in diameter, with a high conical, well-developed operculum. Polyp body with 8 rows of scales, 6 in each abaxial row (Fig. 20B) and 5-6 smaller and slightly disorganized scales in each adaxial row (Fig. 21A).

Eight opercular scales (Fig. 21B, 22A), 0.74$1.22 \times 0.24-0.46 \mathrm{~mm}$, shaped like elongated isosceles triangles. Proximal inner surface tuberculate covering up to half of the length; distal part with numerous longitudinal ridges. Outer surface granular and forming ridges distally. Free margin finely serrated.
Marginal and body scales (Fig. 22B) roughly square to oval-shaped, 0.31-0.64 mm maximum length. Inner surface almost completely tuberculate, outer surface granular, with distal longitudinal ridges. Free margin finely serrated. Scales decreasing in size from abaxial to adaxial side. Eight marginal scales aligned with opercular scales without folding over them; slightly disorganized on the adaxial side.

Geographical and bathymetrical distribution. Plumarella (Faxiella) abietina is only known from the west coast of central America to the Galapagos, at a depth of $3181 \mathrm{~m}$.

Remarks. According to the treatment of Cairns and Bayer (2009), a number of characters would place the new species closer to Acanthoprimnoa Cairns and Bayer, 2004 and Plumarella Gray, 1870: the pinnately colony branching pattern, the disposition of the polyps not being adnate to the coenenchyme, the arrangement of the body scales being complete rows on all sides of the polyps, the marginal scales not folding over the bases of opercular scales, the number of marginal scales and their alignment with the operculars.
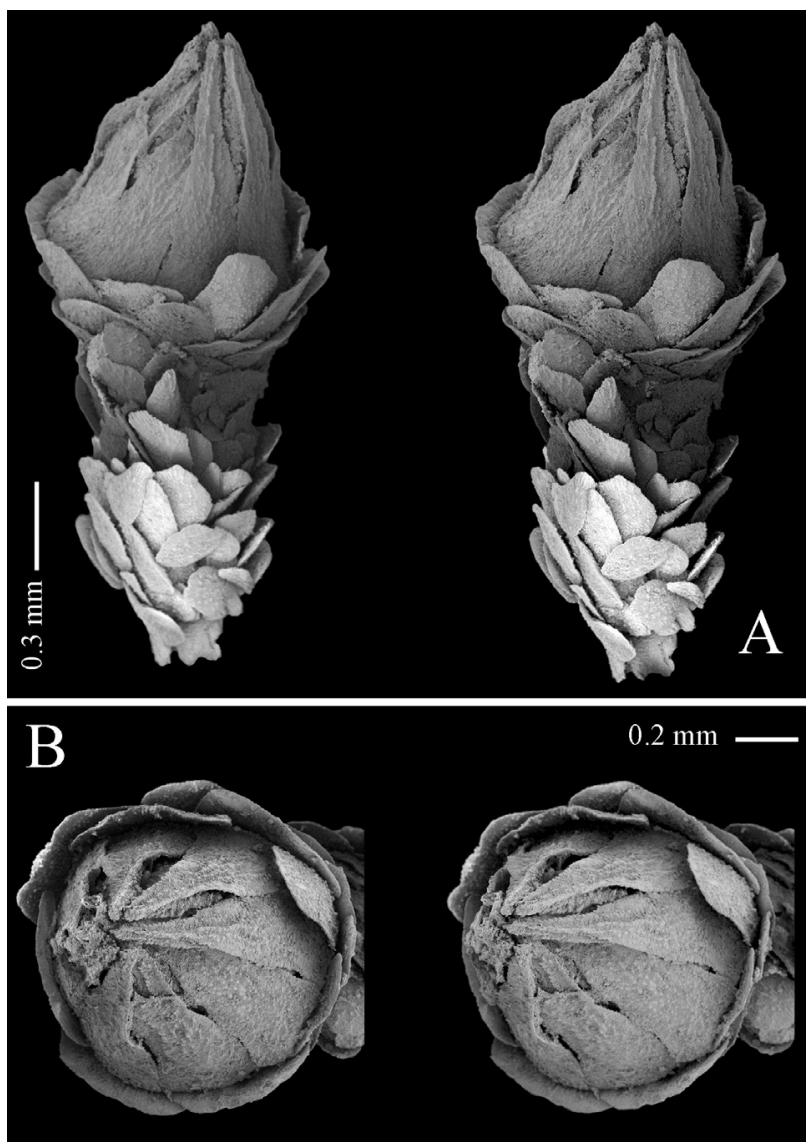

FIG. 21. - Plumarella (Faxiella) abietina (Studer, 1894) n. comb., holotype (MCZ 4802): A, polyp on adaxial view, stereo pair; B, polyp on oral view, stereo pair. [Photo: Stephen D. Cairns, NMNH, Washington]. 


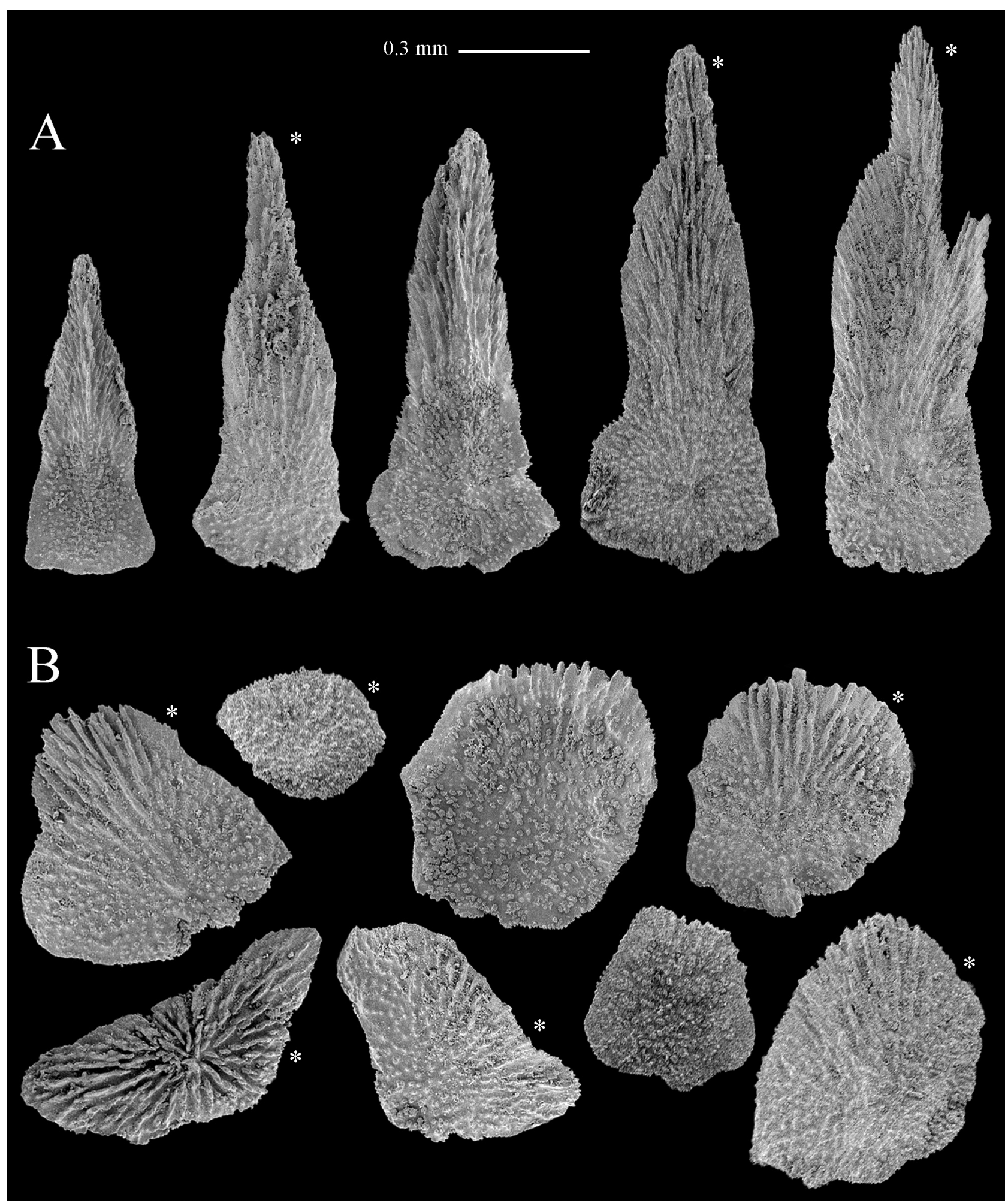

Fig. 22. - Plumarella (Faxiella) abietina (Studer, 1894) n. comb., holotype (MCZ 4802): A, opercular scales; B, marginal and body scales. [*outer surface view; photo: Stephen D. Cairns, NMNH, Washington].

However, the main character of genus Acanthoprimnoa and thus to distinguish from the new subgenus, sclerites with a smooth inner surface and pectinate margins are absent in Faxiella n. subgen.
Although there is a set of characters supporting the inclusion of the new species in the genus Plumarella, we have had to enlarge the limits of the genus to include the arrangement of polyps in pairs. Subsequently, 
following Cairns (2011), who splits Plumarella into 2 subgenera depending on the arrangement of polyps, we propose Faxiella as a new subgenus to accommodate species with paired polyps.

\section{Genus Primnocapsa n. gen.}

Diagnosis. Primnoidae with a planar colony shape and dichotomously branched. Short polyps clubshaped, slightly curved upward to stem and branchlets, singly placed and arranged in spirals. Eight opercular scales with the inner surface keeled and with 2 irregular basal mounds. Eight marginal scales with strong radial ridges on the distal inner surface, offset from the opercular scales. Polyps completely covered by 8 longitudinal rows of body scales reduced in number and size from distal to basal part. Body scales reduced adaxially but always present. Coenenchyme with a single layer of round shaped scales with a central bulk on the inner surface.

Etymology. The generic name combines primno- a common prefix in reference to the gorgonian family, and-capsa, a Latin word meaning box, in reference to the perfect closed operculum like the capsule fruits of some herbaceous plant groups. Gender: feminine.

Type species. Amphilaphis plumacea Thomson and Mackinnon, 1911, here designated.

Remarks. The type material was initially described by Thomson and Mackinnon (1911) as a new species

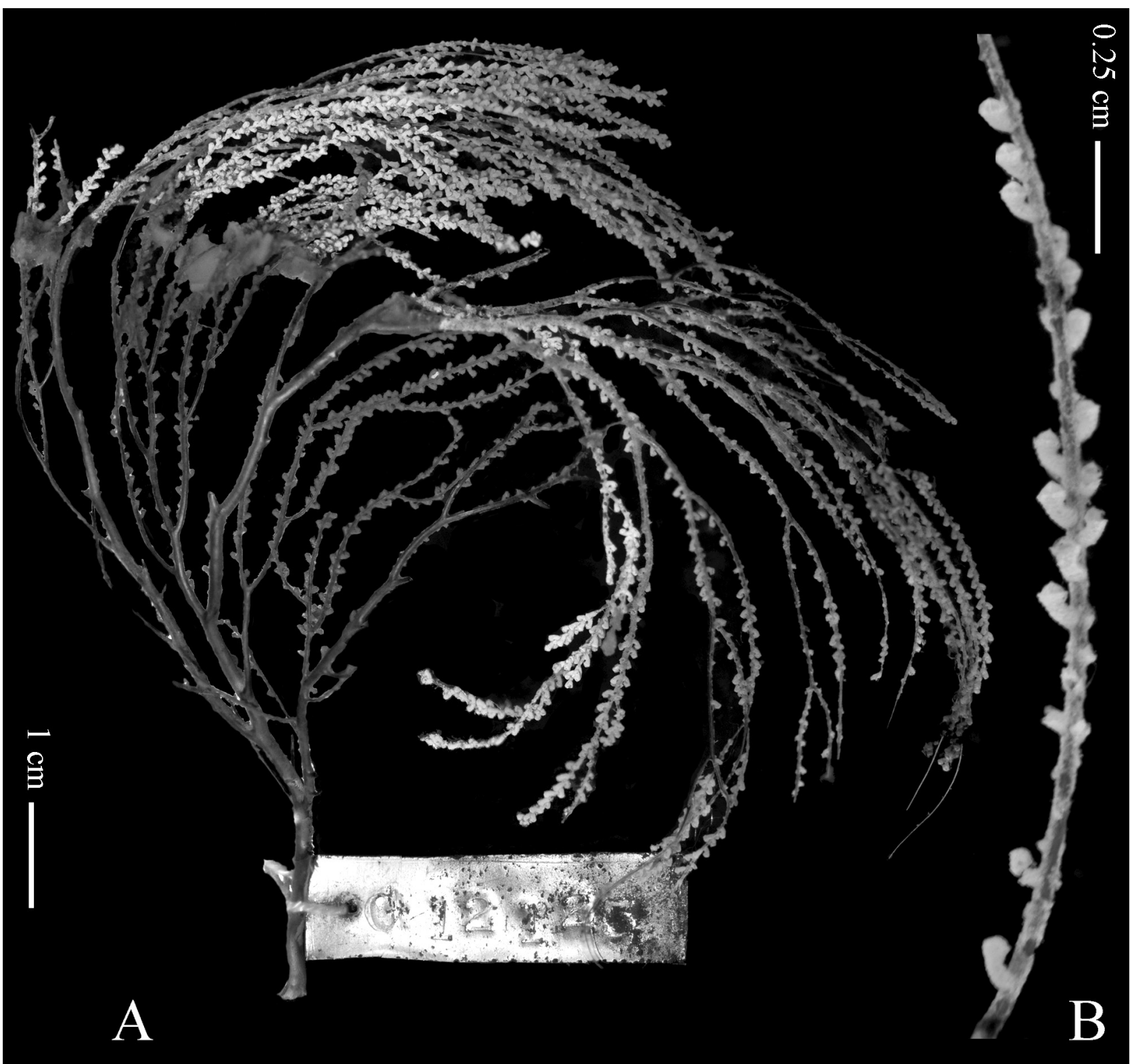

FIG. 23. - Primnocapsa plumacea (Thomson and Mackinnon, 1911) n. comb., holotype (AM G12123): A, whole colony; B, detail of branchlet. 
of the genus Amphilaphis. These authors showed the differences between Amphilaphis plumacea and the species already included in that genus (Thomson and Mackinnon 1911: 681). However, they did not explain why the new species should be included in the genus Amphilaphis. Taking into account that the name Amphilaphis is not available (see remarks on Thouarella regularis in this work) and the characters observed in the re-examined type material, the species cannot be placed in any of the currently described primnoid genera, so a new genus, Primnocapsa n. gen., is hereby proposed for it.

Although we include some of the previous Amphilaphis species in the genus Thouarella, Primnocapsa plumacea $\mathrm{n}$. comb. cannot be included for the following reasons: The opercular scales are not arranged in 2 alternate cycles, marginal scales are offset from the operculars and do not fold over them.

The presence of dichotomously branched colonies, polyps not adnate to the coenechyme, 8 longitudinal rows of sclerites in the polyp, and marginal scales not folding over the operculars, allies the new primnoid genus Primnocapsa n. gen. with the genera Plumarella Gray, 1870, and Acanthoprimnoa Cairns and Bayer, 2004. Primnocapsa $\mathrm{n}$. gen. differs from Plumarella and Acanthoprimnoa, however, because of the presence of a keel on the inner surface of the opercular scales and the different arrangement of polyps on the branchlets, these being in spirals in Primnocapsa n. gen. Other differences between Primnocapsa n. gen., Plumarella and Acanthoprimnoa can be found in the inner proximal structure and the general inner and outer ornamentation of the opercular sclerites (see Fig. 25 in this paper, and Cairns and Bayer 2009: Fig. 11).

As in the genus Parastenella Versluys, 1906, the genus Primnocapsa n. gen. has a dichotomous branching pattern and its 8 opercular scales have a strong keel on their inner surface and are offset from the marginal scales (Versluys 1906: 39, Cairns 2007: 518). However, both genera differ in the orientation of the polyps on the branchlets [perpendicular or downward in Parastenella (see Cairns 2007: 518) and upward in Primnocapsa n. gen. (Fig. 23B)], the shape of the marginal scales [flute-shaped apically in the former (Cairns 2007: 518) and fan-shaped in the latter (Fig. 25B)], and the distinct basal structure of the opercular scales [which have 2 irregular mounds in Primnocapsa n. gen. (Fig. 25A)]. The presence of these irregular mounds on the opercular scales makes it necessary to compare the Primnocapsa n. gen. with the genus Pseudoplumarella Kükenthal, 1915, which was, until now, the only known primnoid genus with this unique opercular locking mechanism (Cairns and Bayer 2009: 48). However, in Primnocapsa n. gen., the branching pattern is dichotomous and the polyps are inclined to the branchlets and not adnate (Fig. 23), the number of marginal scales is 8 , the number of rows of scales on the abaxial side is 3 (Fig. 24A), and adaxial body scales are present (Fig. 24C). In contrast for Pseudoplumarel-
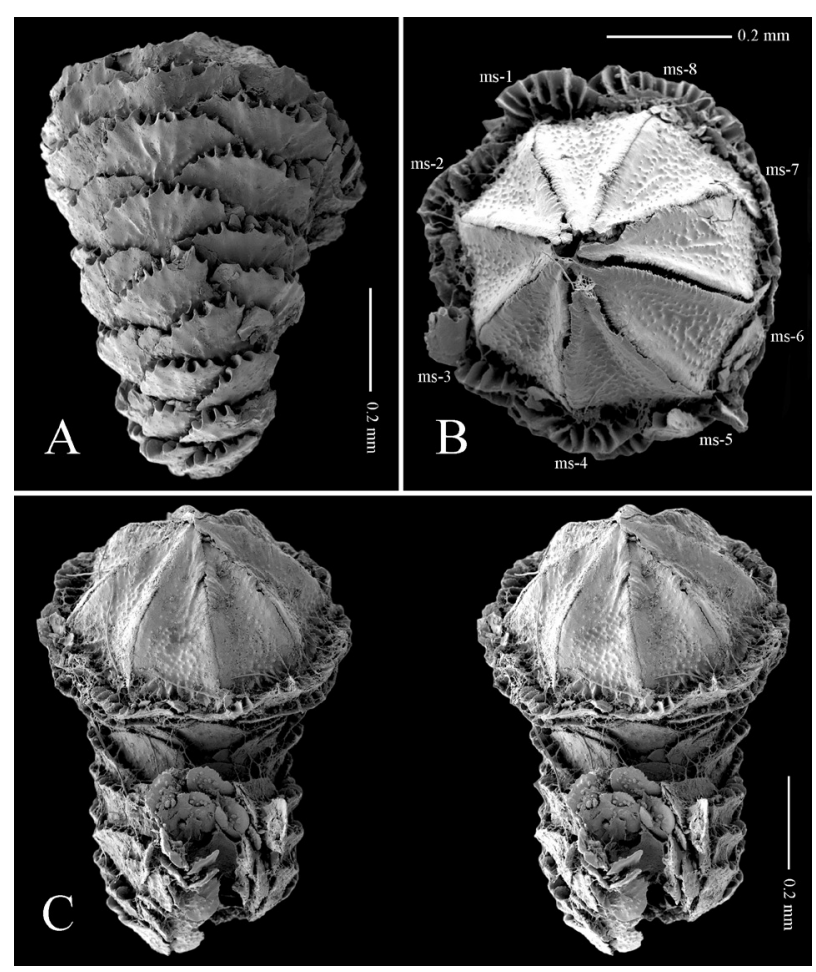

FIg. 24. - Primnocapsa plumacea (Thomson and Mackinnon, 1911) n. comb., holotype (AM G12123): A, polyp on abaxial view; B, polyp on oral view; $\mathrm{C}$, polyp on adaxial view, stereo pair. [ms= marginal scales].

$l a$, the branching pattern is pinnate (see pl. 76-79 in Thomson and Mackinnon 1911, Bayer 1981: 622, Fig. 1, Cairns and Bayer 2009: 48), polyps are adnate to the branchlets (see Fig. 29b in Cairns and Bayer 2009), the number of marginal scales is 5 , the polyps only have one longitudinal row on the abaxial side, and the adaxial body scales below the marginals are absent (Cairns and Bayer 2009: 48).

\section{Primnocapsa plumacea}

(Thomson and Mackinnon, 1911) n. comb. (Figs. 23-25)

Amphilaphis plumacea Thomson and Mackinnon, 1911: 680-681; pl. 65, Fig. 3; pl. 68, Fig. 3; pl.74. Cairns and Bayer 2009: 28. Thouarella (Amphilaphis) plumacea, Kükenthal, 1915: 149. Kükenthal 1919: 414. Kükenthal 1924: 291-292; text Fig. 163.

Examined material. Holotype: AM G12123, Thetis Expedition, "11 miles E. by N. of Barrenjoey", 54.6-73.12 m depth.

Description of the holotype. Planar colony, dichotomously branched (Fig. 23A), $14 \mathrm{~cm}$ high and 5 $\mathrm{cm}$ wide, internodes about 7-21 $\mathrm{mm}$ long and terminal branchlets up to $29 \mathrm{~mm}$. Axis dark brown, stiff, holdfast present. Basal axis diameter $2 \mathrm{~mm}$. Polyps slightly curved upward to stem and branchlets (Fig. 23B), singly placed, and arranged in spirals, 11-15 polyps per $\mathrm{cm}$. They are relatively short (Fig. 24), club-shaped, up to $1.2 \mathrm{~mm}$ tall and $0.36-0.64 \mathrm{~mm}$ in diameter, with a conical operculum. Polyp body with 8 rows of 


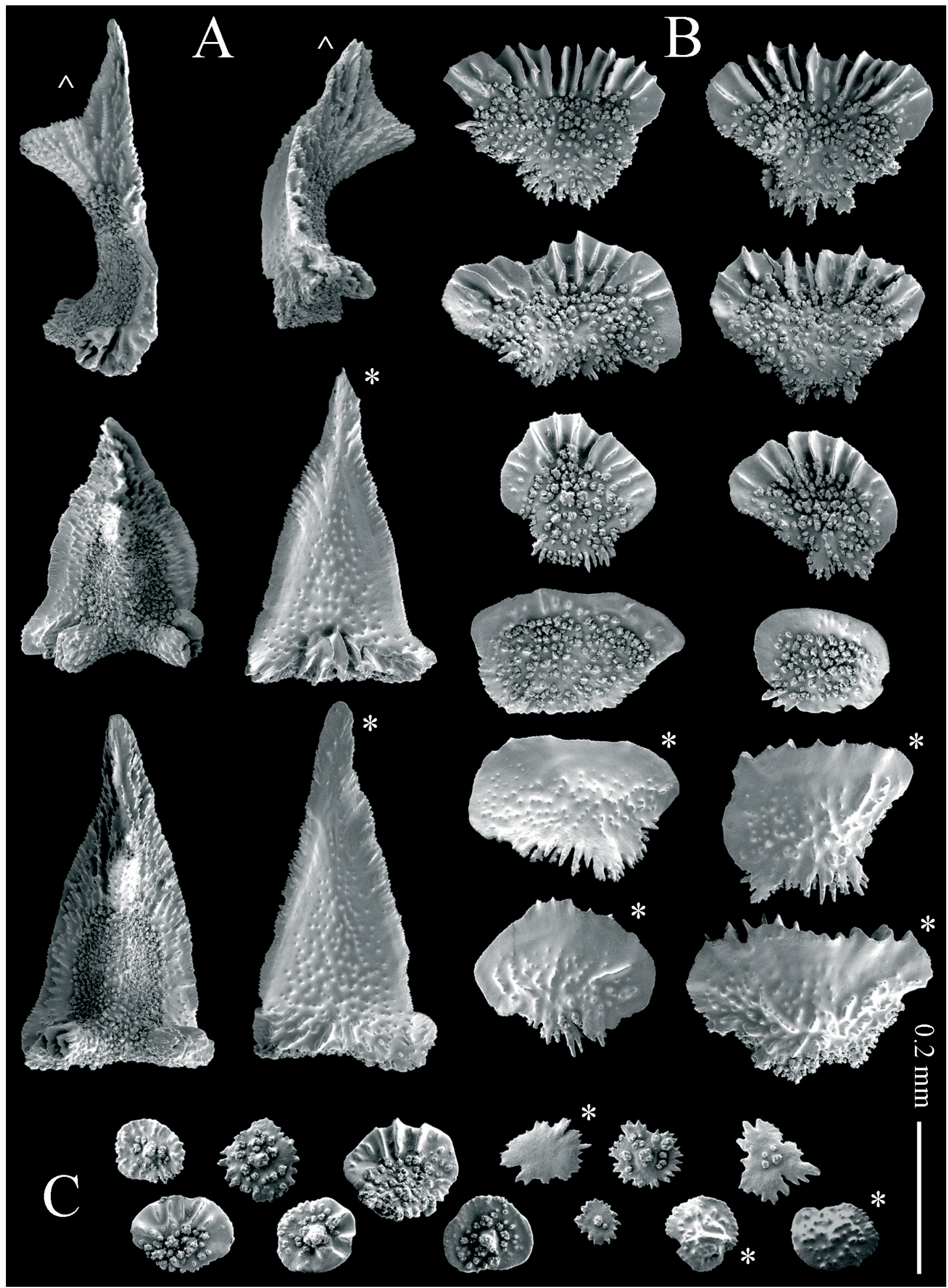

Fig. 25. - Primnocapsa plumacea (Thomson and Mackinnon, 1911) n. comb., holotype (AM G12123): A, opercular scales; B, marginal and body scales; C, coenenchymal sclerites. [* outer surface view; ^ lateral view]. 
scales that are reduced in size and number adaxially. Each abaxial row has 8-12 scales (Fig. 24A) and each adaxial row has 2-3 scales (Fig. 24C). Marginal scales offset from opercular scales (Fig. 24B).

Eight opercular scales (Fig. 24B, 25A), 0.31$0.48 \times 0.22-0.28 \mathrm{~mm}$, isosceles triangle-shaped with an acute apex. Each vertex of the proximal inner surface has an irregular mound articulating with the corresponding mound of adjacent operculars; distal inner surface with a strong prominent keel. Inner surface of free lateral borders and the distal keel with granules forming ridges; remaining inner surface tuberculate. Outer surface of the lateral free borders grooved or smooth, remaining outer surface granular. Free margin finely serrated.

Abaxial marginals and body scales (Fig. 25B) fanshaped, $0.11-0.25 \times 0.14-0.33 \mathrm{~mm}$ with the proximal inner surface tuberculate covering at least $75 \%$ of the scale and strong, distal, radial ridges; adaxials without ridges. Outer surface granular. Free margin finely serrated, basal margin with digitate processes. Scales decrease in number and size from abaxial to adaxial side and from distal to basal portion. The 8 marginal scales offset from opercular scales.

Coenenchymal sclerites (Fig. 25C) round in shape, 0.06-0.15 $\mathrm{mm}$ in maximum diameter. Inner surface tuberculate with a central bulk, edge quite smooth or ridged, outer surface from quite smooth to granular. Margin quite smooth, or with digitate processes.

Geographical and bathymetrical distribution. Primnocapsa plumacea is only known from the type locality off Barrenjoey, Australia (Fig. 1), between 54.6 and $73.12 \mathrm{~m}$ depth.

\section{DISCUSSION}

\section{Taxonomic remarks}

The family Primnoidae is one of the richest in genera and species (Bayer 1998, Cairns and Bayer 2009) and, with the results of the present contribution, currently includes 40 genera and more than 240 species. The first of these species was described in 1763 [Primnoa resedaeformis typica (Gunerus, 1763)] and since then the taxonomy of primnoids has increased considerable. Taxonomists are not only focused on describing new species, they are also constantly revising the more unclear genera (Mirostenella in Zapata-Guardiola and López-González submitted, Thouarella in Taylor et al. submitted). Thanks to these efforts the technology used to describe and identify species has improved, and because the level of precision is higher the assignment of the species to genera is being modified (Cairns and Bayer 2009, present work). The revision and the consequent reassignment of the species previously included in the genus Amphilaphis into an already existing genera (Thouarella and Plumarella) or into a new one (Primnocapsa) make the current classification of the family Primnoidae more understandable, although we need more comprehensive contributions to find a consensus regarding the characters used to cluster species and genera. Some taxonomic characters (e.g. the branching pattern of the colony or the arrangement of polyps on branchlets) have been commonly used to distinguish not only between genera such as Plumarel$l a$ and Parastenella (Bayer 1981, Cairns and Bayer 2009), but also between species of the same genus as in the genus Thouarella (Kükenthal 1924, Cairns and Bayer 2009). Further morphological and molecular studies on species of the family could help to identify generic and specific morphologic characters, as well as a number of possible homoplasies, their evolution through the family Primnoidae and the establishment of relationships among the different taxa.

Biogeography remarks. The 4 Thouarella species here reported are included in the subgenus Epithouarella. Recently, Cairns and Bayer (2009) established the geographical and bathymetrical distribution of Epithouarella species restricted to Antarctic and sub-Antarctic waters from 106 to $686 \mathrm{~m}$ depth. With the new inclusions, the distribution of Epithouarella is found to now involve the mid-Pacific Ocean with records up to $6400 \mathrm{~m}$ depth.

The different collection localities of the species of Thouarella studied confirm the presence of the genus in places like Gauss Station, where only one species, T. longispinosa Kükenthal, 1912 was previously reported, and Tristan da Cunha, where only T. affinis was previously recorded. Furthermore, the distribution of the species of Thouarella has also been extended, with T. vitjaz being the first record in the mid-Pacific Ocean (between Marshall and Johnston Atoll and Hawaiian archipelago). On a bathymetric scale, the maximum depth for a Thouarella species has been attributed to the holotype material of T. flabellata Kükenthal, 1907 with 1644 m (Kükenthal 1907: 208), but the new species $T$. vitjaz widely exceeds that finding, reaching $6400 \mathrm{~m}$ in depth. Additionally, the bathymetric range at some localities has been extended, as for Tristan da Cunha where Thouarella is currently known to occur from 130 to $660 \mathrm{~m}$ depth, and for Gauss Station, where the depth increases to $2450 \mathrm{~m}$.

The new species Thouarella vitjaz enlarges the geographical and bathymetrical distribution of the family Primnoidae at $6400 \mathrm{~m}$ depth, being the deepest known primnoid and octocoral, exceeding the deepest pennatulacean Umbellula found at $6100 \mathrm{~m}$ depth (Williams 1995, 2011). Though the species here reported have been included in different genera, they had already been included in this family. The family Primnoidae, which includes 40 genera (15 of them monotypic) and 244 species, is found in all oceans, even the polar ones. Only 3 primnoid genera (Narella Gray, 1870, Plumarella and Thouarella) have a worldwide distribution (Atlantic, Pacific, Indian, Subarctic and Southern oceans), 2 of them being also the most speciose genera (Thouarella and Narella, with 40 and 
38 species respectively). The biogeographical region with the greatest number of primnoid genera is the Southern Ocean, with 24 (60\% of the total), 9 of them being monotypic, closely followed by the Pacific and Atlantic oceans with 23 and 14 genera respectively. Further to them we find the sub-Arctic with 8 genera and the Indian Ocean with only 5 genera recorded. However, the major number of species is found in the Pacific Ocean, with almost half of the primnoid species currently accepted (117), while in the Southern Ocean we only find a quarter of the total number of species. Despite this, the Southern Ocean is characterized by a great endemicity of primnoid genera $(63 \%)$, doubling the percentage found in the Pacific Ocean (30\%). In the other regions, endemicity is lower or does not exist, as in the sub-Arctic and Indian oceans.

To summarize, the family Primnoidae shows a high diversity in the Southern Ocean, with a greater grade of endemism in this region than in any other. This fact agrees with the patterns reported for other invertebrate groups (Arntz et al. 1997, Rodríguez et al. 2007). To explain this high diversity and level of endemism in Antarctic waters and surrounding areas, Clarke and Crame (1992) suggested that the climatic fluctuations during a long evolutionary history of the region have led to benthic fauna being concentrated at the poles, forming Antarctic ecosystems that are comparable with those in tropical and temperate regions. Moreover, there is evidence from mollusc fossil discoveries (Crame 1999) and phylogenetic variations in fishes (Bargelloni et al. 2000) of the dispersion and evolution of the Antarctic species being displaced outwards by gradations in diversity. These facts have caused Antarctica to be proposed as a marine centre of diversity (Briggs 2003). In this way, Antarctica will produce a regular pool of successful ancestral species capable of spreading to the nearest areas and becoming widely distributed outward in contrast to the derived species that will form the local populations (Briggs 2003). Strong similarities have been reported between South America and Antarctic regions for some invertebrate taxa (Rodriguez et al. 2007, Griffiths et al. 2009), but the direction of the linkage is uncertain. Antarctica has also been proposed as an immigrant receptor for opportunistic colonists, being able to combine both behaviours (drain and donor) at the same time (Briggs 2003, Griffiths et al. 2009). Primnoids are highly represented in the Southern Ocean and further biogeographical and population genetic analyses are required to confirm and define those connections, and to confirm Antarctica as a hotspot for primnoid biodiversity.

\section{ACKNOWLEDGEMENTS}

The authors would like to thank E.J. Beglinger (ZMA), E. Sherlock (NHMUK), S.D. Cairns (NMNH), S. Keable (AM), A. Baldinger (MCZ), L. Carsten and C. Radken (ZMB), B.M. Pokryszko (MNHW) and T.N. Molodtsova (IORAS) for lending the specimens examined in this study and for their useful and constant assistance. Special thanks to Stephen D. Cairns for the SEM analysis of Faxiella abietina n. comb. and for his invaluable help during the short stay at the Smithsonian Institution. Also thanks to M. Taylor for letting us know some of the changes that will be proposed in the future classification of the genus Thouarella. Special thanks are also given to Josep M. Gili as well as to the editor of Scientia Marina and the referees for their ideas and comments about the manuscript, which really improved it. Support for this work was provided by the Spanish CICYT project POL2006-06399/CGL (CLIMANT). Mr. Tony Krupa is thanked for reviewing the English version.

\section{REFERENCES}

Alderslade P. 1998. Revisionary systematics in the gorgonian family Isididae, with description of numerous new taxa (Coelenterata, Octocorallia). Rec. W. Aust. Mus. 55: 1-359.

Arntz W.E., Gutt J., Klages M. 1997. Antarctic marine biodiversity: an overview. In: Battaglia B., Valencia J., Walton D.W.H. (eds.), Antarctic Communities: species, structure and survival. Cambridge Univ. Press, pp. 3-14.

Bargelloni L., Stephani M. Zane, Patarnello L. T. 2000. Mitochondrial phylogeny of notothenioids: a molecular approach to Antarctic fish evolution and biogeography. Syst. Biol. 49: 114-129.

Briggs J.C. 2003. Marine centres of origin as evolutionary engines. J. Biogeogr. 30: 1-18.

Bayer F.M. 1980. Armadillogorgia cyathella and Ophidiogorgia paradoxa, two new genera and species of primnoid octocorals (Coelenterata: Anthozoa) from South Georgia and South Orkney Islands. Proc. Biol. Soc. Wash. 93(1): 216-228.

Bayer F.M. 1981. Key to the genera of Octocorallia exclusive of Pennatulacea (Coelenterata: Anthozoa), with diagnoses of new taxa. Proc. Biol. Soc. Wash. 94(3): 901-947.

Bayer F.M. 1988. Mirostenella articulata, a remarkable new genus and species of primnoid octocoral with uncalcified axial nodes. Proc. Biol. Soc. Wash. 101(2): 251-256.

Bayer F.M. 1996. New Primnoid Gorgonians (Coelenterata: Octocorallia) from Antarctic waters. Bull. Mar. Sci. 58(2): 511-530.

Bayer F.M. 1998. A review of the circumaustral gorgonacean genus Fannyella Gray, 1870 with description of five new species (Coelenterata: Octocorallia: Primnoidae). Senckenb. Biol. 77(2): 161-204

Bayer F.M., Stefani J. 1989. Primnoidae (Gorgonacea) de NouvelleCalédonie. Bull. Mus. Natl. His. Nat. Paris (4) 10(A) 3: 449-476.

Bayer F.M., Grasshoff M., Verseveldt J. 1983. Illustrated trilingual glossary of morphological and anatomical terms applied to Octocorallia. E.J. Brill/Dr. W. Backhuys, Leiden, 75 pp.

Cairns S.D. 2007. Studies on western Atlantic Octocorallia (Gorgonacea: Primnoidae). Part 8: New records of Primnoidae from the New England and Corner Rise Seamounts. Proc. Biol. Soc. Wash. 120(3): 243-263.

Cairns S.D. 2010. Review of Octocorallia (Cnidaria: Anthozoa) from Hawai'i and Adjacent Seamounts. Part 3: Genera Thouarella, Plumarella, Callogorgia, Fanellia and Parastenella. Pac. Sci. 64(3): 413-440.

Cairns S.D. 2011. A Revision of the Primnoidae (Octocorallia: Alcyonacea) from the Aleutian Islands and Bering Sea. Smithson. Contrib. Zool. 634: 1-55.

Cairns S.D., Bayer F.M. 2009. A Generic Revision and Phylogenetic Analysis of the Primnoidae (Cnidaria: Octocorallia). Smithson. Contrib. Zool. 629: 1-79.

Clarke A., Crame J.A. 1992. The Southern Ocean benthic fauna and climate change: a historical perspective. Philos. Trans. R. Soc. Lond. B. 338(1285): 299-309.

Crame J.A. 1999. An evolutionary perspective on marine faunal connections between southernmost South America and Antarctica. Sci. Mar. 63(1): 1-14.

Griffiths H.J., Barnes D.K.A., Linse K. 2009. Towards a general- 
ized biogeography of the Southern Ocean benthos. J. Biogeogr. 36: $162-177$

Kinoshita K. 1908a. Gorgonacea no ikka Primnoidae ni tsuite. Dobutsugaku zasshi 20(242): 517-528.

Kinoshita K. 1908b. Diplocalyptra, eine neue Untergattung von Thouarella (Primnoidae). Annot. Zool. Jap. 7(1): 49-60.

Kükenthal W. 1907. Gorgoniden der Deutschen Tiefsee-Expedition. Zool. Anz. 31(7): 202-212.

Kükenthal W. 1912. Die Alcyonaria der deutschen Sudpolar Expedition 1901-1903. Dtsch. Sudpolar-Exped. 13. Zoologie 5(3): 289-349.

Kükenthal W. 1915. System und Stammesgeshichte der Primnoidae. Zool. Anz. 46 (5): 142-158.

Kükenthal W. 1919. Gorgonaria. Wiss. Ergebn. Dtsch. TiefseeExped. "Valdivia" 13(2): 1-946.

Kükenthal W. 1924. Dass Tierreich 47. Coelenterata: Gorgonaria. Walter de Gruyter \& Co., Berlin, 478 pp.

López-González P.J., Gili J.M. 2002. A new primnoid genus (Anthozoa: Octocorallia) from the Southern Ocean. Sci. Mar. 66(4): 383-397.

Menneking F. 1905. Uber die Anordnung der Schuppen und das Kanalsystem bei Stachyodes ambigua (Stud.), Caligorgia flabellum (Ehrb.), Calyptrophora agassizii (Stud.), Amphilaphis abietina (Stud.) und Thouarella variabilis (Stud.). Arch. Naturgesch. 71, 1(3): 245-266, pls. 8-9.

Nutting C.C. 1908. Descriptions of the Alcyonaria collected by the U.S. Bureau of Fisheries steamer Albatross in the vicinity of the Hawaiian Islands in 1902. Proc. U. S. Natl. Mus. 34: 543-601.

Pasternak F.A. 1981. Alcyonacea and Gorgonacea. In: Kuznetsov AP, Mironov AN (eds.), Benthos of the submarine mountains Marcus-Necker and adjacent Pacific regions. Moscow, Akad. Nauk. 40-55.

International Commission on Zoological Nomenclature. 1999. International Code of Zoological Nomenclature, $4^{\text {th }}$ edition. London: International trust for Zoological Nomenclature, c/o Natural History Museum, London.
Rodríguez E., López-Gonzáez P.J., Gili J.M. 2007. Biogeography of Antarctic sea anemones (Anthozoa, Actiniaria): What do they tell us about the origin of the Antarctic benthic fauna? Deep-Sea Res. Part. II 54: 1876-1904.

Studer T. 1887. Versuch eines systems der Alcyonaria. Arch. Naturgesch. 53(1): 1-74.

Thomson J.A., Mackinnon D.L. 1911. The alcyonarians of the "Thetis" Expedition. Aust. Mus. Mem. 4: 661-695.

Versluys J. 1906. Die Gorgoniden der Siboga-Expedition. II. Die Primnoidae. Siboga-Exped. 13a: 1-187.

Williams G.C. 1995. Living genera of sea pens (Coelenterata: Octocorallia: Pennatulacea): illustrated key and synopses. Zool. J. Linn. Soc. 113: 93-140.

Williams G.C. 2011. The global diversity of Sea pens (Cnidaria: Octocorallia: Pennatulacea). PLoS ONE 6(7): e22747. doi:10.1371/journal.pone.0022747.

Wright E.P., Studer T. 1889. Report on the Alcyonaria collected by H.M.S. Challenger during the years 1873-1876. Rep. Sci. Res. Voyage H.M.S. Challenger during the years 1873-76. Zool. 31:i-lxxvii, 1-314.

Zapata-Guardiola R., López-González P.J. 2010a. Four new species of Thouarella (Anthozoa: Octocorallia: Primnoidae) from Antarctic waters. Sci. Mar. 74(1): 131-146.

Zapata-Guardiola R., López-González P.J. 2010b. Two new gorgonian genera (Octocorallia: Primnoidae) from Southern Ocean waters. Polar Biol. 33: 313-320.

Zapata-Guardiola R., López-González P.J. 2010c. Two new species of Antarctic gorgonians (Octocorallia: Primnoidae) with a redescription of Thouarella laxa Versluys, 1906. Helg. Mar. Res. 64: $169-180$.

Scient. ed.: D. Vaqué.

Guest ed.: J.M. Gili.

Received October 14, 2010. Accepted September 21, 2011.

Published onlline January 18, 2012. 